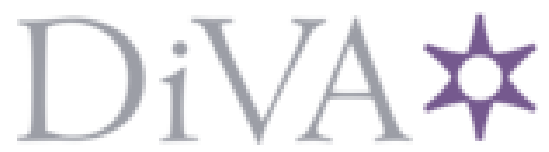

http://www.diva-portal.org

\title{
Postprint
}

This is the accepted version of a paper published in Journal of African Archaeology. This paper has been peer-reviewed but does not include the final publisher proof-corrections or journal pagination.

Citation for the original published paper (version of record):

Widgren, M., Maggs, T., Plikk, A., Risberg, J., Schoeman, M H. et al. (2016)

Precolonial agricultural terracing in Bokoni, South Africa: Typology and an exploratory excavation.

Journal of African Archaeology, 14(1): 33-53

https://doi.org/10.3213/2191-5784-10281

Access to the published version may require subscription.

N.B. When citing this work, cite the original published paper.

Permanent link to this version:

http://urn.kb.se/resolve?urn=urn:nbn:se:su:diva-126245 


\section{Precolonial agricultural terracing in Bokoni, South Africa: Typology and an exploratory excavation}

Mats Widgren, ${ }^{1}$ Tim Maggs, ${ }^{2}$ Anna Plikk, ${ }^{3}$ Jan Risberg, ${ }^{3}$ Maria H. Schoeman, ${ }^{4}$ Lars-Ove Westerberg ${ }^{3,5}$

Corresponding author: Mats Widgren mats.widgren@humangeo.su.se

January 2016

This is the authors' final version of paper accepted for publication in Journal of African Archaeology. The published version will be accessible at

http://www.african-archaeology.de/

\footnotetext{
${ }^{1}$ Department of Human Geography, Stockholm University, 10691 Stockholm, Sweden, mats.widgren@ humangeo.su.se (corresponding author)

${ }^{2}$ Department of Archaeology, University of Cape Town

${ }^{3}$ Department of Physical Geography, Stockholm University

${ }^{4}$ School of Geography, Archaeology and Environmental Studies, University of the Witwatersrand

${ }^{5}$ Bolin Centre for Climate Research, Stockholm University
} 
Abstract: Earlier work on the terraced settlements of the Bokoni area $\left(16^{\text {th }}\right.$ to $19^{\text {th }}$ century, Mpumalanga province, South Africa) focussed on the homesteads, their contents, layout and chronology. This paper suggests a terminology and typology of agrarian structures in Bokoni in order to improve comparative approaches in Africa and beyond. The typology and an excavation of the terracing have made possible preliminary conclusions relevant for the further analysis of the terracing and stone-walling in Bokoni. The terracing developed incrementally, whereby cultivation, stone-clearing and terracing were intermixed processes. This is supported both by the organic content in a section of a terrace and by a phytolith analysis. The phytolith analysis furthermore indicated that maize was cultivated on the terraces, but this should be seen as a pilot study only, and presence of maize in Bokoni must be tested with other archaeobotanical methods.

Resumé: Des recherches antérieurs sur les paysage de terrasses de la région Bokoni (16e-19e siècles dans la province de Mpumalanga, Afrique du Sud) se sont concentrés sur les fermes, leur organisation spatiale et de la chronologie. Nous proposons ici une terminologie et une typologie des éléments agraires dans Bokoni afin d'améliorer les approches comparatives en Afrique et au-delà. Cette typologie et une excavation d'une terrasse a rendu possible conclusions préliminaires sur la croissance du terrassement et les murs de pierre dans Bokoni. Le terrassement a été développé incrémentielle, de sorte que la préparation du sol, l'épierrement et le terrassement ont été processus mélangés. La conclusion est soutenu à la fois par le contenu organique dans une section d'une terrasse et d'une analyse des phytolithes. L'analyse des phytolithes a en outre indiqué que le maïs a été cultivé sur les terrasses, mais cela devrait être considéré comme une conclusion préliminaire seulement, et la présence de maïs dans Bokoni doit être testé avec des autres méthodes archaeobotaniques.

\section{Bokoni terracing in the wider context}

Agricultural terracing constitutes one of the most widespread types of enduring human modifications of land globally and an important signature of past agriculture. Since the global overview by Spencer and Hale (1961) our understanding of the distribution, dating and causes of this phenomenon has advanced. Archaeological investigations of terracing have moved from surface analysis and dating based on associations between terracing and nearby monuments to more much more detailed analyses of construction and dating (see e.g. Acabado 2012; Frederick and Krahtopoulou 2000; Bevan et al. 2013).

Overviews of terracing in sub-Saharan Africa from an historical perspective are provided by Grove \& Sutton (1989) and for West Africa by Widgren (2010a). Since the overview by Grove and Sutton new archaeological research has given insights into terrace construction and dating in Tanzania (Stump 2006, 2010) and Kenya (Davies 2014). But more important in this context are the advances in Southern Africa during the last 15 years. In 1989, when Grove and Sutton published their overview, the large terrace system in Nyanga (Zimbabwe) was only rudimentary known and published, and the reliability in the reports on the terracing in what is now termed Bokoni in South Africa was considered unclear (Grove \& Sutton 198: 122). Since then Robert Soper's extensive and well documented monograph on Nyanga has provided us both with a synthesis and the detailed evidence for comparative purposes (Soper 2002) and the research on the terraced agriculture in Mpumalanga, South Africa has advanced considerably.

The Bokoni sites have been known to archaeologists since the early twentieth century (Pijper 1918; van Hoepen 1939), and considerable research has been done on them, particularly 
during the 1970s (reviewed in Delius \& Schoeman 2008). These sites have now been the focus of a renewed interest, and have recently been set in a new context based on the one hand on a new understanding of the relation between the archaeological sites and the oral histories (Delius \& Schoeman 2008; Delius et al. 2014; Wright 2010;), and on the other hand through a contextualisation of these sites and their agricultural remains within the broader history of intensive agriculture and terracing in sub-Saharan Africa (Maggs 2008; Stump 2010). Our current project is the first to attempt a detailed examination of the complex agricultural system.

The stonewalled and terraced sites in Bokoni marks a $150 \mathrm{~km}$ long zone in the undulating middle veld between the towns of Orighstad and Carolina in Mpumalanga Province, in eastern South Africa. Bokoni (the land of the Koni people) is the oldest name that has survived for this area of the Great Escarpment in Mpumalanga Province. The name has come down to us through the oral traditions of neighbouring people especially the Pedi, recorded in the nineteenth century (see Delius \& Schoeman 2008 for detailed discussion)..

While the origin of these settlement forms and agricultural terracing has not yet been scientifically dated, these sites probably date within the last 500 years. Oral histories recount that people associated with Bokoni were living in the region by the seventeenth century. Bokoni expanded north to the new capital Mohlo Pela and other areas such as Khutwaneng ${ }^{5}$ after the abandonment of Moxomatsi in the seventeenth century (Delius \& Schoeman 2008: 157-158; Prinsloo 1936: 11). Occupations in Khutwaneng continued into the nineteenth century. In the 1970s one of these sites was dated to the early nineteenth century using radio carbon dating (Hall \& Vogel 1980: 254). Obviously, the accuracy of this date is uncertain, but is supported by the presence of nineteenth century glass beads at the site.

The five sites mentioned in this paper represent most of the Bokoni sequence. Komati Gorge appears to be associated with the first phase of occupation mentioned in the oral traditions. Rietvlei site is located in the general area where the second capital, Moxomatsi, was said to be, and thus probably dates to the seventeenth century. The Verlorenkloof and the Badfontein/Klipfontein terracing probably formed part of the seventeenth to nineteenth century Khutwaneng settlement complex. The Orighstad dam sites probably are contemporaneous with Khutwaneng.

The period of abandonment is better understood and dated. The start of the collapse of Bokoni as an independent polity is connected to the political developments in the early 1800s with intensive raiding in the area and the subsequent establishment of Pedi sovereignty over the former Bokoni polity associated with these sites. By the 1830s the majority of the open air settlements seem to have been abandoned in favour of more defensive sites or refugia (Delius \& Schoeman 2008: 154-156 ). Most of these defensive sites do not contain agricultural terracing. Consequently, it is likely that the agricultural practices, that helped to shape the architecture of this region, ended during this period.

\footnotetext{
${ }^{5}$ The indigenous name for the Badfontein valley that stretches north from Verlorenkloof.
} 


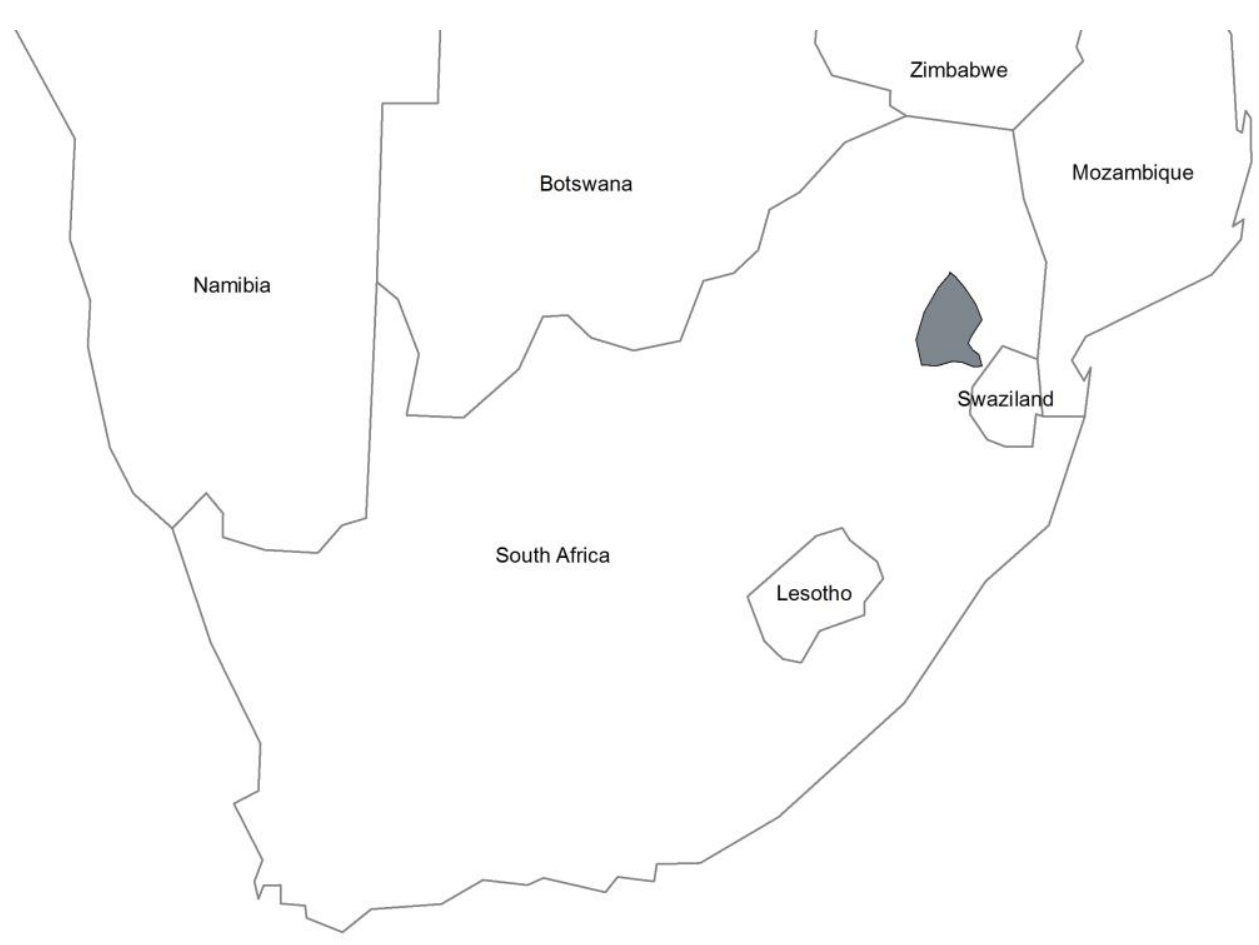

Figure 1. Location of the Bokoni area in Mpumalanga, South Africa

The political and economic complexity that developed in the region between the sixteenth and nineteenth centuries, in part can be connected to trade from the east coast around Maputo. It has been suggested that the Bokoni community acted as intermediaries in this trade and also supplied cattle and agricultural surplus to the coast (Delius \& Schoeman 2008: 163). Historical sources indicate that there was substantial regional trade with areas less fertile in agricultural produce (Delius 1983: 17). The combination of internal political and economic growth, combined with the need to produce a surplus for international / regional trade, probably spurred agricultural intensification in Bokoni.

International trade also introduced new crops. For our purposes the most important new crop is maize, which probably entered southern Africa via the Indian Ocean coast. The earliest direct evidence for maize from Mpumalanga Province comes from the mfecane ${ }^{6}$ period site of Esikhujini to the west of Bokoni (Schoeman 1998: 77). Further south, in Kwazulu-Natal, there is both historical (Hedges 1978) and archaeological evidence for maize as a staple crop well before European colonisation in the early nineteenth century. The two sites of Nqabeni (Hall \& Maggs 1979) and Mgoduyanuka (Maggs 1982), both in the interior regions of KwaZulu-Natal, have produced evidence of substantial consumption of maize by the eighteenth century, if not earlier. Huffman (1996), largely on the occurrence of large lower grindstones, has suggested that maize as a staple was quite widespread in South Africa by the end of the eighteenth century. On the other hand Boeyens (2003) cautions, from detailed historical sources, that maize did not reach as far west as the Tswana peoples until about the 1830 s.

Following the discussion by Maggs (2008) it can be argued that maize also may have been cultivated in the Bokoni area (2008: 180). The only physical evidence for maize so far is from the grinding stones that are of a large type usually regarded as being required for the grinding

\footnotetext{
${ }^{6}$ Early 19th century period of conflict in southern Africa. See Hamilton (1996) for more detail..
} 
of maize and not the smaller African grains. Maize would have a much higher yield per hectare than the African grains, such as sorghum and millet, in this relatively well watered escarpment region (cf. McCann 2005: 26). It can also be argued that the cultivation of maize, with its better response to input of nitrogen and water, could have been a factor behind the building of terraces for soil conservation and water retention and also the possible use of manure (cf Farré \& Faci 2006, and Carr 2014). The question of the crops in Bokoni especially the introduction of new types, and the proportion of maize vs. other grains is therefore a crucial element in the further exploration of Bokoni agriculture.

The extensive agricultural terracing, as well as the long, walled cattle roads, stand witness to a close integration between animal husbandry and the cultivation of crops. Maggs (2008) has compared the evidence from the area with specialised regimes of agriculture in eastern Africa during the same period and raised a series of questions that needs to be addressed in Bokoni to further this comparative approach (Maggs 2008: 178-180). Besides the obvious signs of terracing some of the other indications of a labour intensive agriculture in Bokoni need to be corroborated with further research. Central in this question is the degree to which animal husbandry and crop cultivation were integrated not only spatially, but also functionally. Were the cattle stall-fed and was the manure distributed on the fields and did this possibly lead to the formation of organic rich anthropogenic soils?

Systems based on stall-fed cattle and manuring are rare in the southern African context. The only real indication of this in the region emanates from the Nyanga area in Zimbabwe, where the stall-feeding and collection of manure has been interpreted based on the archaeological remains (Soper 2002: 126-128).

\section{Aim}

It is against this background that this exploratory paper sets out

1) to suggest a terminology and typology of agrarian structures in Bokoni in order to improve comparative approaches in Africa and beyond

2) on the basis of that typology to initiate a discussion on the process of labour investment involved in the building of the stone-walled and terraced landscape

3) to explore ways to further investigate the character of farming and the crops involved in Bokoni 


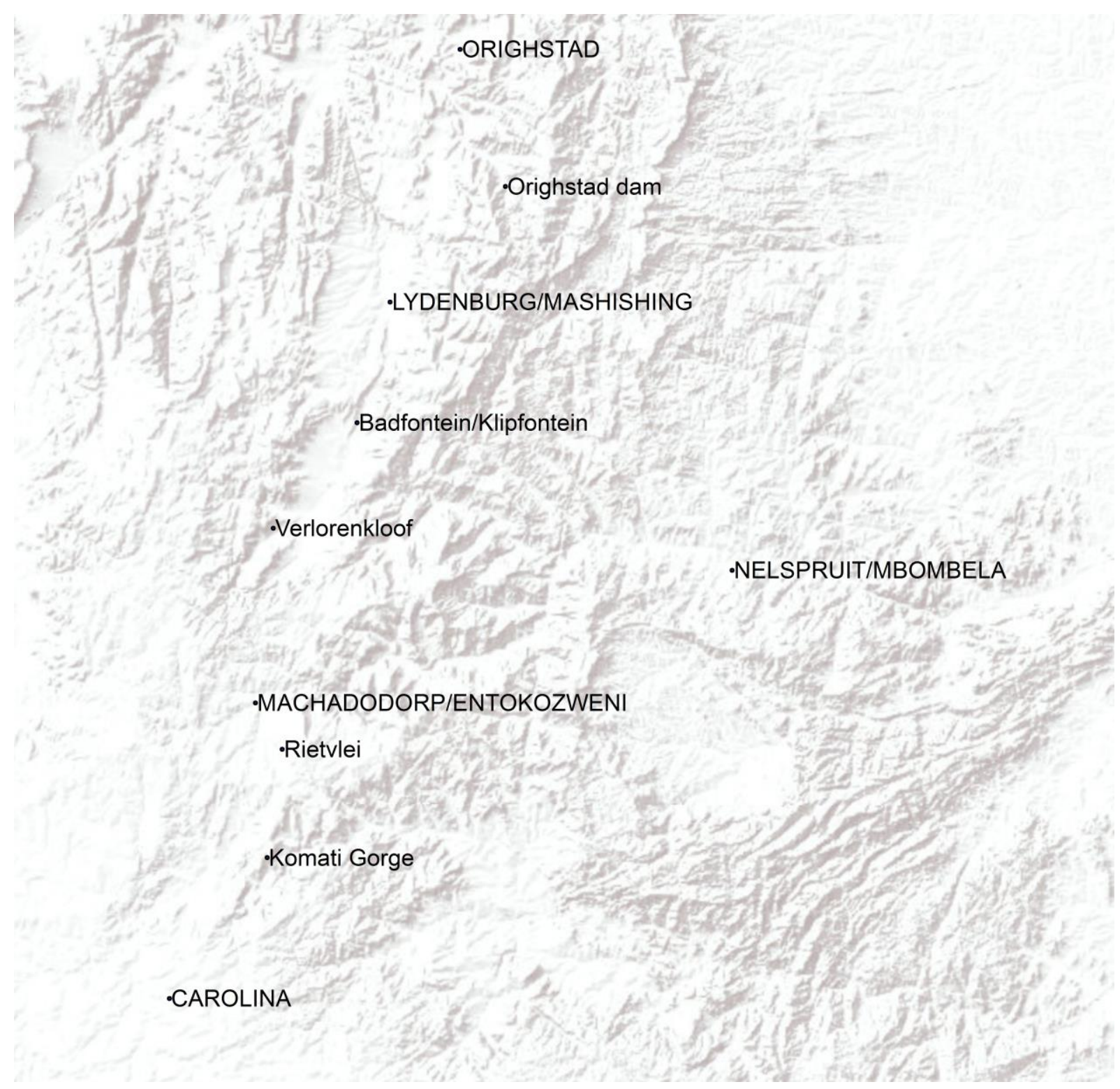

Figure 2. . Sites in which field observations and excavations for this paper were carried out (lower case). Upper case: towns.

\section{Typology of terraces and other field structures in Bokoni}

While earlier work on the terraced settlements of Bokoni concentrated on the homesteads, their contents, layout and chronology (Evers 1973, 1975, Collet 1982), little attention was paid to the rich evidence for intensified agricultural production which is unique in the record of precolonial farming in South Africa. This paper therefore represents the first attempt to examine this evidence in detail and to compare it with other pre-industrial agricultural systems in other parts of Africa and the wider world.

In the previous literature the traces of cultivation in Bokoni have usually been referred to as 'terracing'. Field observation by our team has revealed a more complex situation, and it is now clear that the precolonial cultivators used a variety of techniques to improve the productivity of the land. It is now possible to propose a typology consisting of several different construction techniques, although the results are still based on a limited number of observations. 
The 'terraces' show a wide range of variation from those with substantial, well-built, near vertical walls to low and unordered irregular lines of stone and earth. In addition to that distinction the other forms resulting from cultivation need to be defined. With reference to the terminology and typology that is used in studies of European ancient fields and in studies of terracing in the Americas we are proposing the following terminology. ${ }^{7}$

\footnotetext{
${ }^{7}$ Cf Taylor 1975, Denecke 1979, Treacy and Denevan 1994, Fries 1995, Gren 1997 and Grove and Rackham 2001. The typology is based on observations from sites with agricultural terracing and other traces of cultivation at Ohrigstad Dam Reserve, Komati Gorge, Badfontein/Klipfontein and more detailed recordings in Rietvlei, as well as observations and excavations at Verlorenkloof in Nov-Dec 2010.
} 

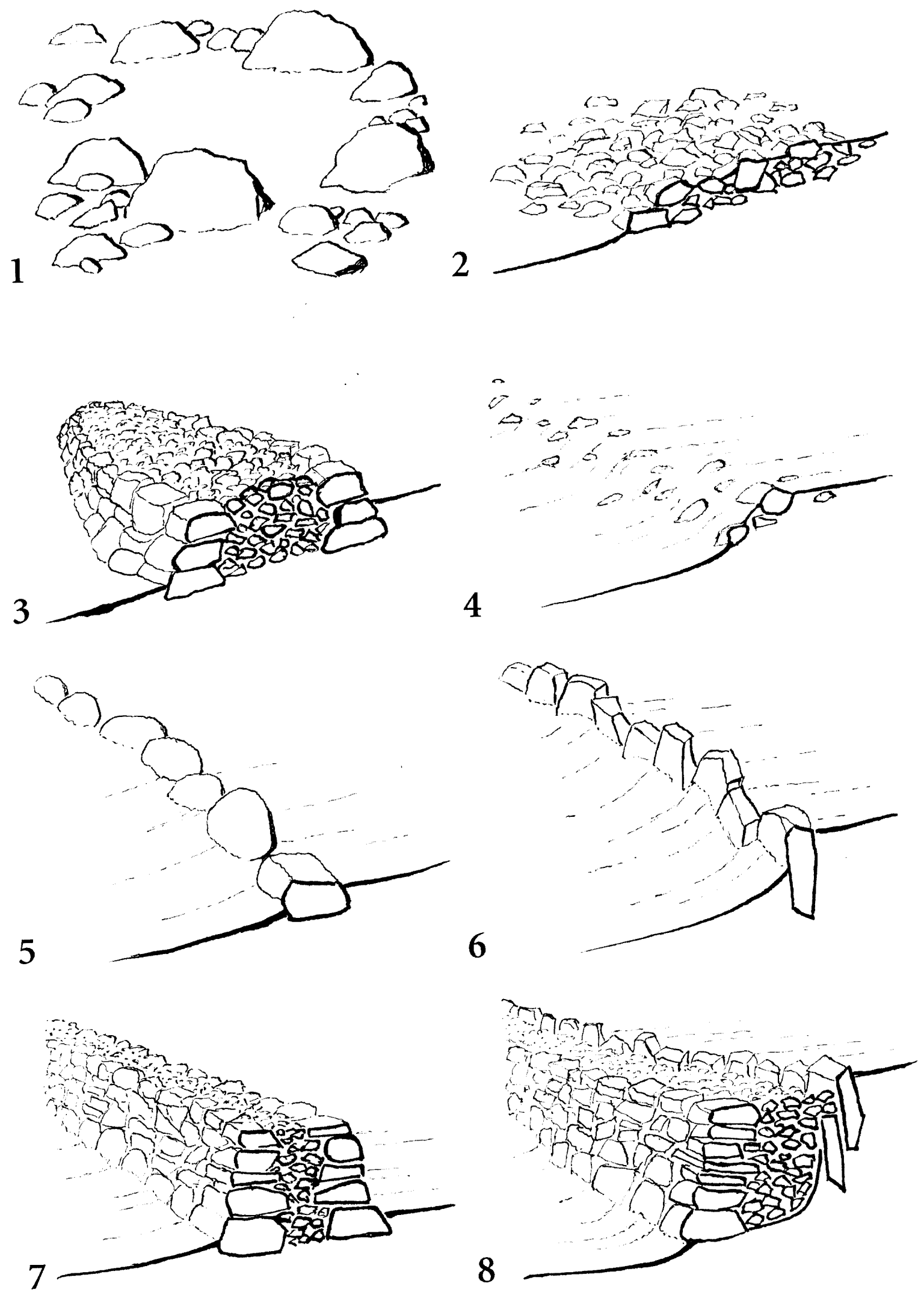
Figure 3 Agricultural features in the Bokoni landscape. 1) Stone cleared surfaces 2) Clearance cairn, rock pile,

3) Clearance cairn, faced 4) Lynchet 5) Stone line, plain stones, 6) Stone line, upright slabs 7 Double faced wall,

8) Terrace wall developed from line of upright slabs (Drawing Tim Maggs)

\section{Stone Cleared Surfaces}

Starting with the least modified type of cultivation surface, we find that in some rocky areas the smaller stones have been moved to provide patches of soil suitable for hoe cultivation. Stone cleared surfaces have been identified in Sweden as a particular type of ancient field (Sw. röjda ytor, Gren 1997: 99-100). These surfaces are usually small and irregularly circular. Larger stones may be left in place, the cleared stones tending to form an irregular row around the periphery of the surface (Fig.3: type 1 and Fig. 4). Identification of stone cleared surfaces requires careful consideration of the natural occurrence of stones and boulders in the local terrain. These features have so far been identified at Komati Gorge and Rietvlei, the latter examples being no more than a few square metres of cultivable area. Further examples are likely to be found at many other Bokoni localities.

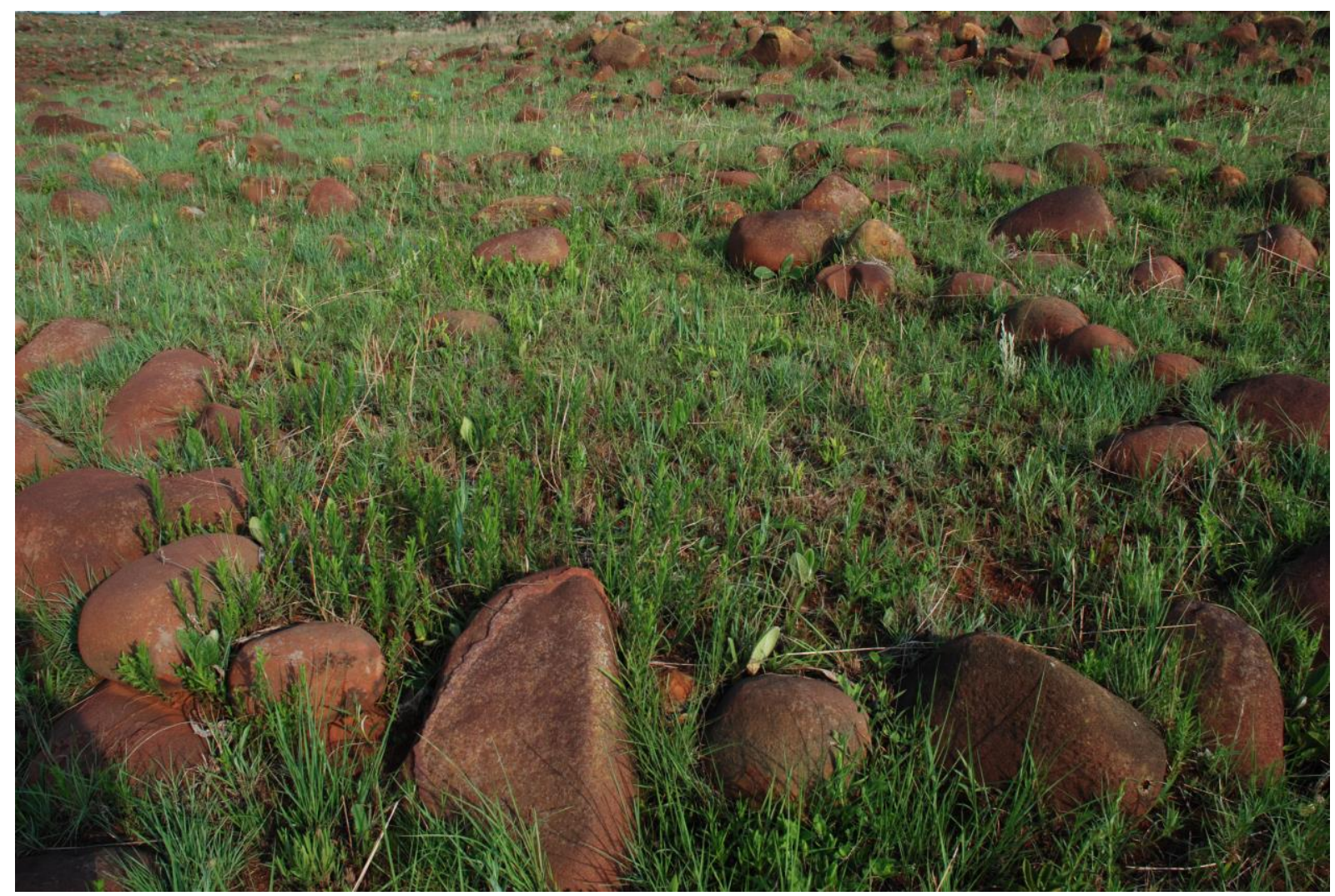

Figure 4 Stone cleared surface at a north facing slope in Rietvlei

\section{Clearance cairns}

The clearance cairns can be subdivided broadly into two types: rock piles and faced clearance cairns.

\section{Clearance Cairns: Rock Piles}

Scattered through the field systems are circular to oval or irregular piles of cobbles including pebbles and even small boulders (Fig. 3, type 2). They can be found overlaying walls, lynchets and terraces, and may also have formed the bases of lynchets as can be seen on the shores of Ohrigstad Dam where the fluctuating water levels have removed the soil thus exposing the rock piles (Fig. 5). Wherever they occur they are witness to an ongoing clearing of mostly palm-sized stones from the cultivated fields. 
Areas in which numerous rock piles attest to manual cultivation are known from KwaZuluNatal in the south (Maggs et al. 1986: 474) to Limpopo in the north (J. van Schalkwyk pers. comm. 2011). These may indeed be the only direct evidence, that has survived through time, of precolonial field systems in South Africa beyond the Bokoni region, though as yet little research has been done on them. Similar cairns can be found in many regions of the world and are well known in northern Europe where large cairnfields consisting of such features date from the Bronze Age to the medieval period (Widgren 2010b).

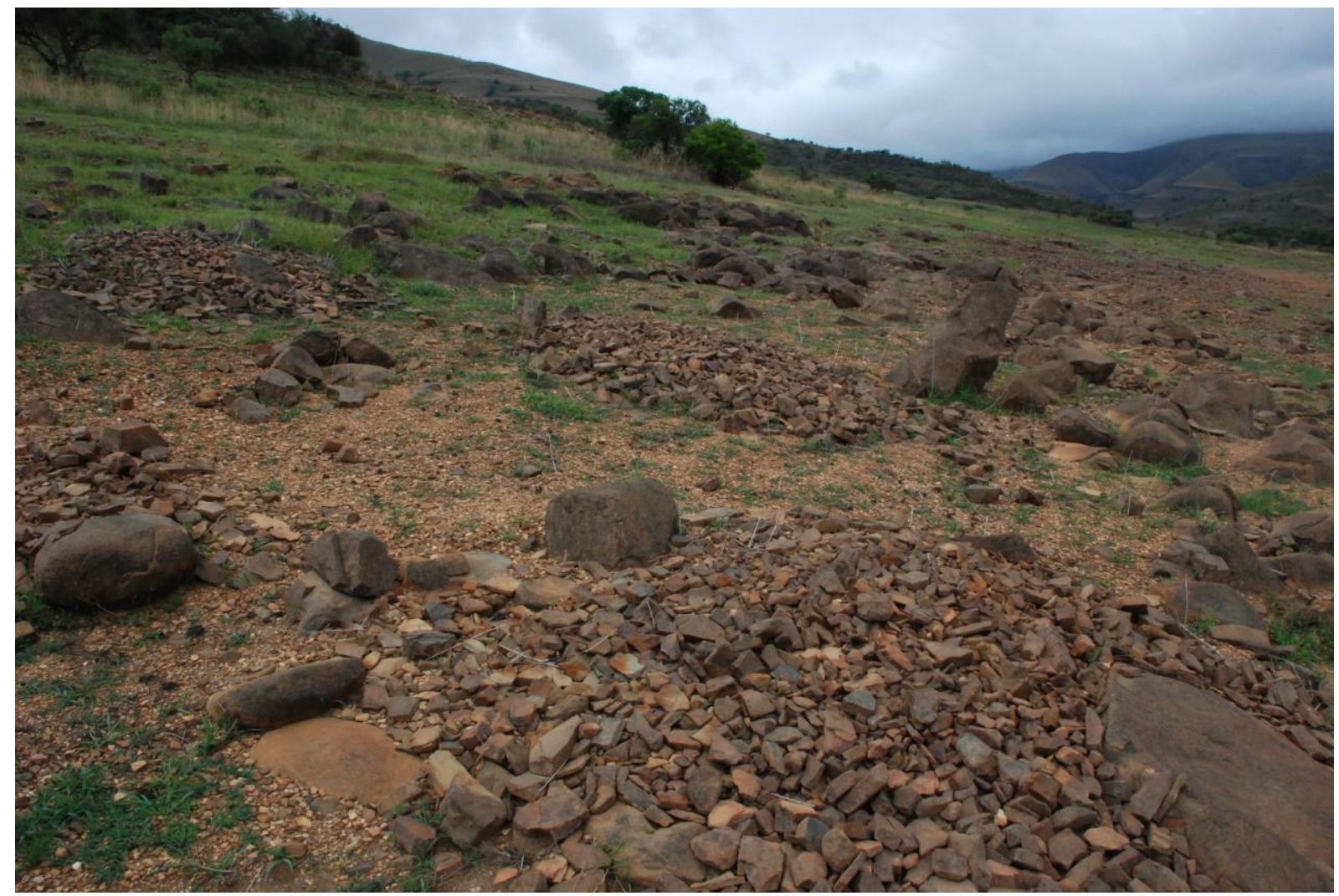

Figure 5. Clearance cairns of rock pile type in the Ohrigstad dam area. Note that the present bare appearance is the result of the erosion caused by the fluctuating levels of the dam. Before that erosion this area most probably looked like the landscape in Fig. 8, which is only some 100-200 metres above this picture.

\section{Clearance Cairns: Faced}

The faced type of cairn, which has a more formal structure than the last type may have a more limited distribution in Bokoni. Here the margins of the cairn are defined by well-built and near-vertical faces of larger stones which form a container for the internal rubble of smaller stones (Fig 3, type 3; Fig 6). This type may resemble the Phiri (=hyena) cairns built during adult male initiation ceremonies by communities such as the Pedi (eg. Monnig 1967: 120. We are grateful to J. van Schalkwyk for pointing out this possibility). However the examples we have recorded occur within field systems and relatively close to homesteads so are not likely to have had their origin in these secluded ceremonial observances. The faced cairns also tend to be elongated and sometimes take the form of a wider section within a wall of a homestead, cattle road or terrace, such examples clearly being designed to accommodate an excess of stones.

Similar features from the ancient field system of Engaruka in Tanzania are called by Sutton (2000: 15) "angular faced cairns" or "faced stone heaps", while Stump (2006: 154) describes them as having "well-coursed walls around a rubble in-fill". Possible explanations for the Engaruka examples, besides being containers for field stones, are that they may have 
functioned as bird-scaring platforms or as bases for storing and drying manure (Sutton 2000: 16). In the Swedish context clearance cairns with almost vertical faces usually indicate times or places when and where stone clearing had continued for quite a while, the land being too valuable to allow space to be wasted under sloppily formed rock piles.

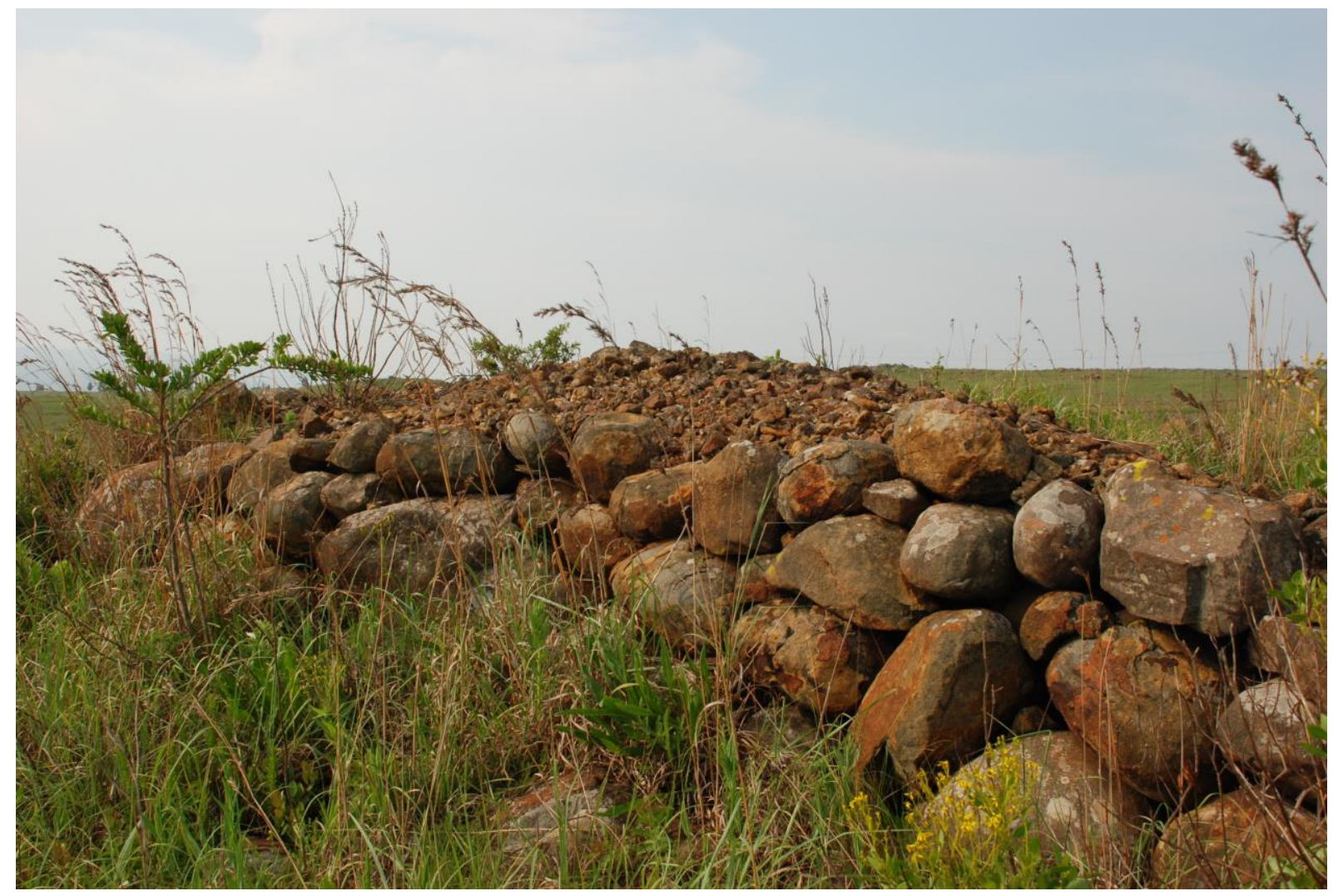

Figure 6. Faced clearance cairn close to an abandoned settlement at Rietvlei,

\section{Lynchets}

The term lynchet (French: rideaux) has mainly been defined in the European context and is best known in connection with strip ploughing: "A bank formed at the end of a field by soil which, loosened by the plough, gradually moves down slope through a combination of gravity and erosion". ${ }^{8}$ Lynchets thus develop roughly along the contours. As defined here, the role of the plough in lynchet formation is only for the loosening of the soil, while the formation of the lynchet itself is more dependent on erosion caused by gravity than on the tilling implement. Lynchets formed by cross-plowing with an ard are also well documented in Europe (Taylor 1975: 28).

Lynchets can also develop when the land is hoed by hand. They are formed when a field boundary in sloping land, originally consisting of an untilled bank, is respected during several seasons and not hoed over. While the erosion of the cultivated soil is the main factor behind the formation of lynchets, the successive accretion of stones cleared from the fields and thrown on to the bank can lead to the development of a linear bank mixed with stones and soil. In a more precise terminology the cut at the upper end of acultivated surface is called a negative lynchet, while the lower edge is a positive lynchet (Fig. 7).

\footnotetext{
${ }^{8} \mathrm{http}: / /$ thesaurus.english-heritage.org.uk (accessed 2011-02-28), in French the term rideaux is used (Aufrère 1929)
} 
Different forms of less organised terracing and other intermediate forms between "proper" terraces as described below and lynchets can be observed on Bokoni sites (Fig.3, type 4) and may in some instances best be compared with the rock rubble terraces as shown by Doolittle (2000: 292). However, a system of distinct lynchets was observed in an area east of the Ohrigstad dam. The cultivated surface here lack sharply defined edges on their up and down hill sides. The positive lynchets comprise a combination of stones and soil, with stones cleared from the fields sometimes protruding from the surface (Fig. 8).

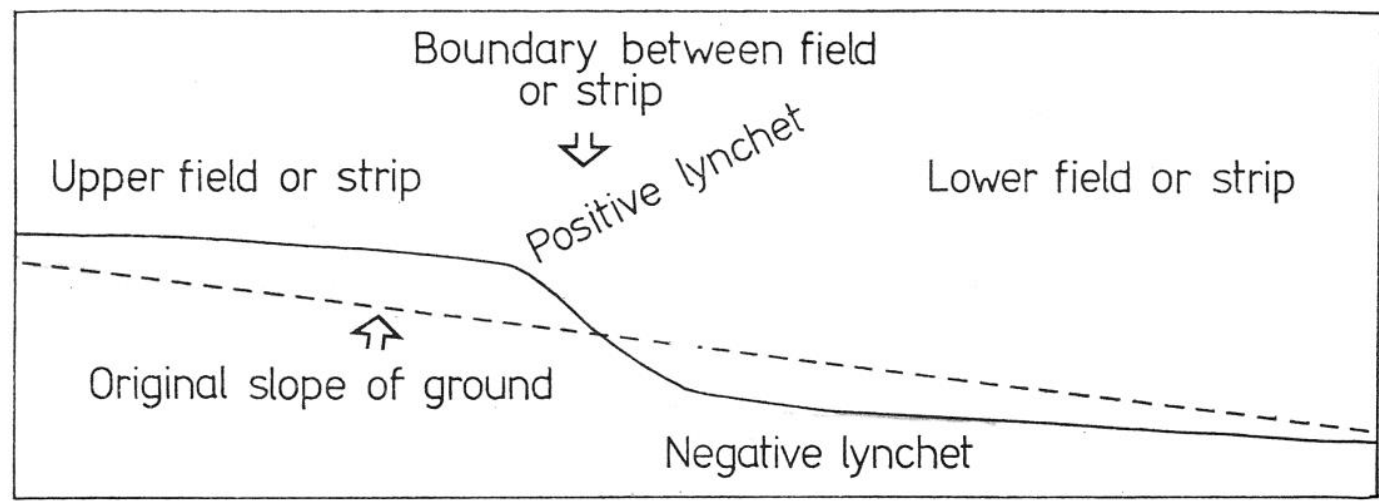

Figure 7. Lynchet formation and terminology according to Taylor 1975: 35

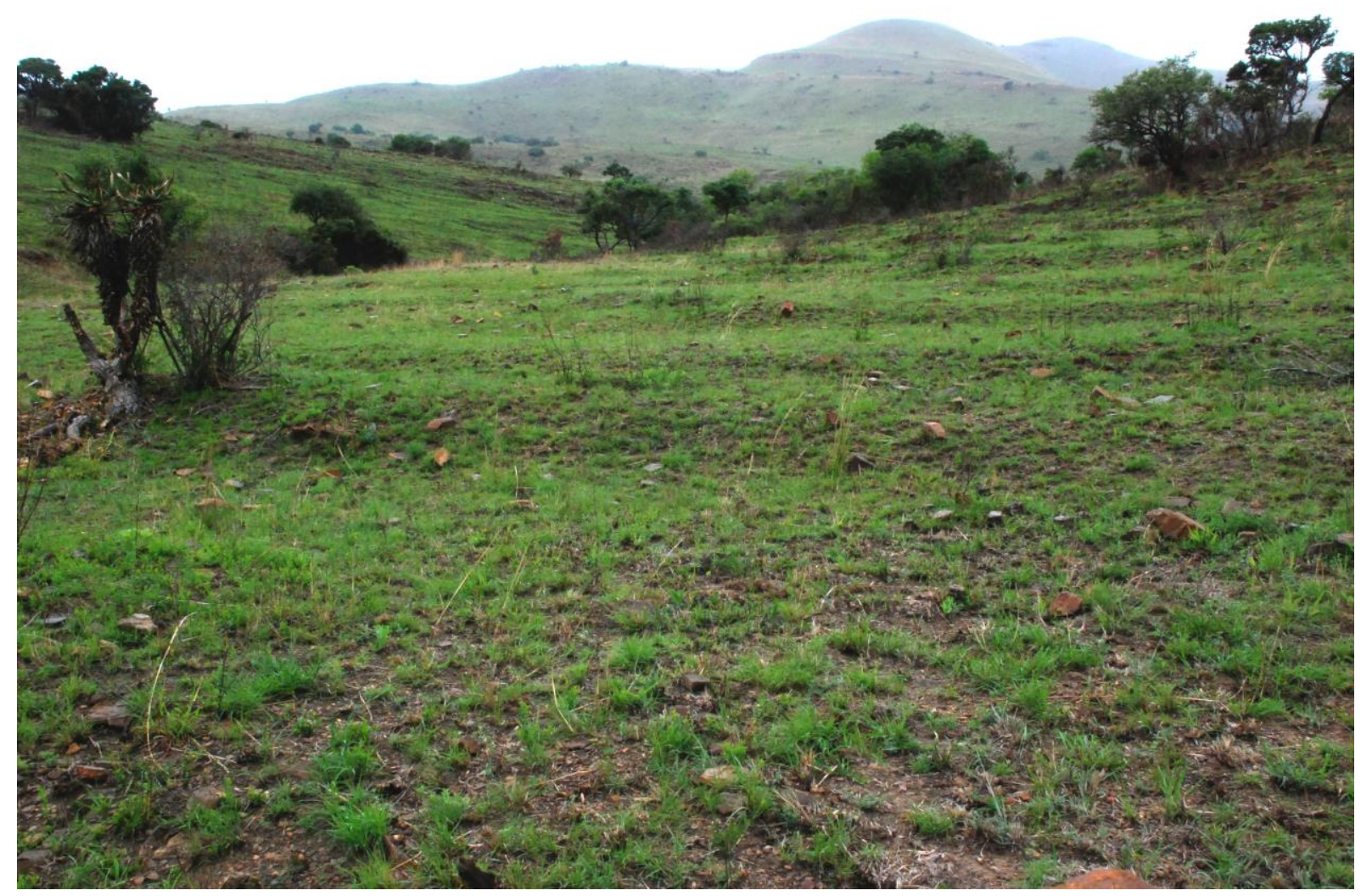

Figure 8. A system of lynchets east of Orighstad Dam

\section{Stone Lines}

Here again these can be divided into two types: lines of plain stones and lines of upright slabs. 


\section{Lines of Plain Stones}

These consist of a single row of stones, usually of moderate size such that they can be carried by one person. They are not highly selected but tend to be rotund in shape. Such lines are usually placed roughly along a contour where they may form an incipient terrace. Other stones may be casually added to this line contributing to the effect of a rough terrace.

These lines also occur running down slope, in which case they serve as boundary markers between individual cultivated plots. Clear examples of this are evident as internal divisions of the cultivated terraces at Verlorenkloof (see Fig. 9). They are also found as radial divisions within the domestic areas of homesteads.

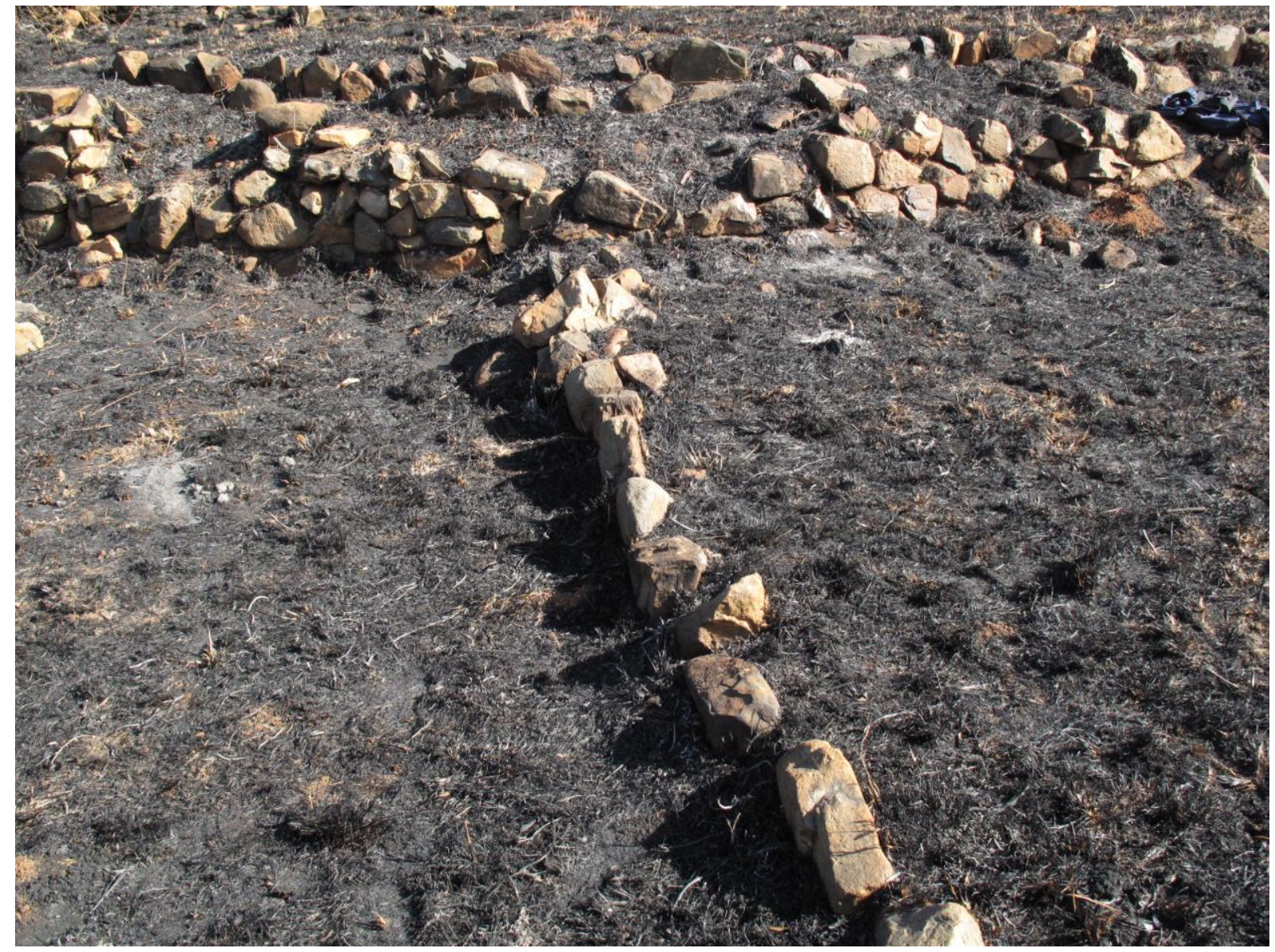

Figure 9. Line of plain stones at Verlorenkloof, cutting across a cultivated terrace to mark the boundary between two plots

The best comparative examples, in form and function, are "traditional stone lines" in the Dogon area (Kassogué et al. 1996), the lines of stones that delimit the "stone bounded fields" of Engaruka (Stump 2006: 153, 233-234) and the lines of stones across terraces in Nyanga (Soper 2002: 36-37) . In native North America similar features are also common. Doolittle describes for Mexico the use of brush and single rows of cobbles creating low rock terraces used "primarily to distribute sheetflow evenly across a field" (Doolittle 1984: 129). Similarly Lindsay describes from Utah linear borders "formed primarily of field stones the width and height of a single rock laid side-by-side" which "served several purposes which include: clearing stones from the farm land to facilitate cultivation, retaining soil at the site of the alignments, and impeding and spreading runoff" (Lindsay 1961). 


\section{Lines of Upright Slabs}

By contrast with the previous type, the stones used here have been carefully selected for their flat shape and moderately large size. They are set with their long axes vertically into the ground and in a single row, touching 'shoulder to shoulder', roughly along a contour. They thus form a robust and effective trap for sediments washing down slope (Fig.3, type 6). It seems likely that this form developed out of the previous type as the Bokoni cultivators came to realise the need for more effective measures against soil erosion and rapid rainwater runoff.

The lines of upright slabs differ from most of the stone lines from other parts of the world mentioned above, but they are a distinguishing and indeed essential element in Bokoni agricultural practice, as will be evident from the discussion of terraces below. We have seen these lines of upright slabs from northern to southern areas of Bokoni and in a variety of geological environments, including sedimentary formations where flat slabs of sandstone/quartzite are readily available, as well as igneous formations where most loose rocks tend to be rounder in shape. At Ohrigstad dam they are particularly evident where fluctuating water levels have washed away much of the previously overlying soil (Fig. 10).

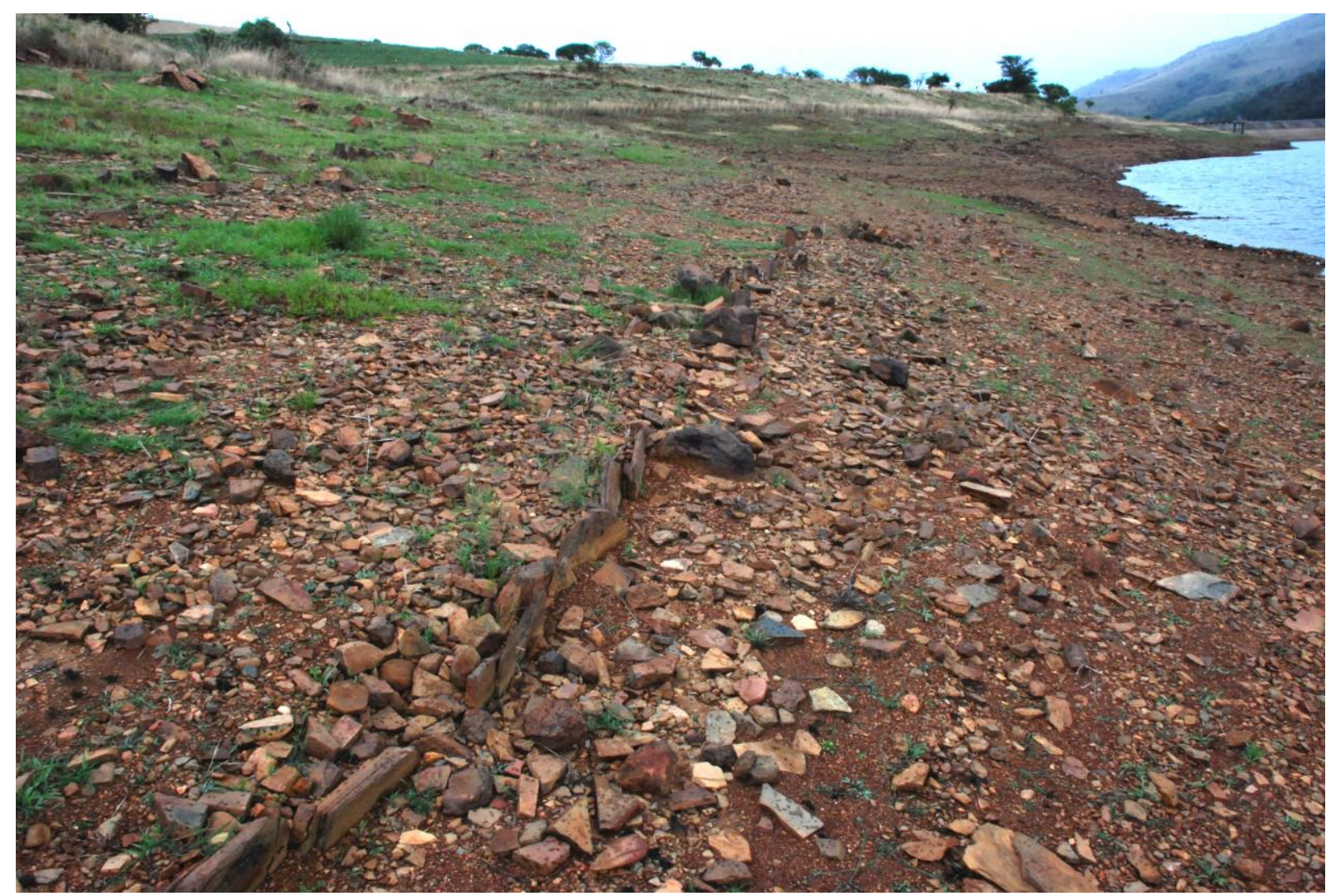

Figure 10. Line of upright slabs uncovered by dam, west of Orighstad dam

\section{Walls}

As in Bokoni, the great majority of walls built by precolonial communities in southern Africa share a basic pattern. In these dry-stone walls the two faces are carefully built with larger stones, the centre being filled with smaller stones and rubble (Fig. 3, type 7). The faces are built to a batter so that the top of the wall is narrower than the base. The angle of the batter depends to some extent on the prevailing shape of the local stone, thus irregular or rounded shapes require more batter to provide a stable structure, while more rectangular and slab-like forms permit more vertical faces. As mentioned above, the pattern of construction is like that of the faced cairns. 
In most of these precolonial communities stone walls form livestock enclosures and may also define domestic spaces. But in Bokoni they serve a wider range of functions including the delineation of livestock roads through cultivated areas, and sometimes the separation of cultivation from grazing areas. In a few cases we have also noted walls which mark boundaries between individual cultivated plots. In cases where terrace walls rise above ground level on the uphill side, the structure takes on this form with two faces and rubble centre. We have yet to excavate an example of this kind of terrace so do not know if this structural form continues below the soil surface.

Much of the extensive terracing in the highlands of eastern Zimbabwe is described as being built to this pattern (Soper 2002: 45), and at an early stage of the present project it seemed likely that this was the case at Bokoni as well. Our recent fieldwork has however revealed quite a different system of terrace construction.

\section{Terraces at Verlorenkloof}

A major aim of our current research has been to develop an understanding of terracing in Bokoni. This includes the construction of the terrace retaining walls, the development of soil on the terraces and a first attempt to date the process. Fieldwork was carried out at Verlorenkloof where a small part of a field system was surveyed to record the general layout and distribution of different features (Fig. 11). The survey covers about 1.2 hectares, with steeper slopes towards the top terraces which are to the west, and gentler slopes eastwards and towards the stream banks. Gradient varies from about 8 to 5 degrees and less, the steeper slopes to the east being left unterraced. Most Bokoni terracing we have measured is on slopes of between 5 and 10 degrees with a few examples up to 13 degrees. Terraces run only roughly on the contour and their surfaces are not as level as would be needed for irrigation. We have found no evidence of irrigation, the Bokoni region being one of the better watered areas of southern Africa, with mean annual rainfall around 600 to $900 \mathrm{~mm}$. 


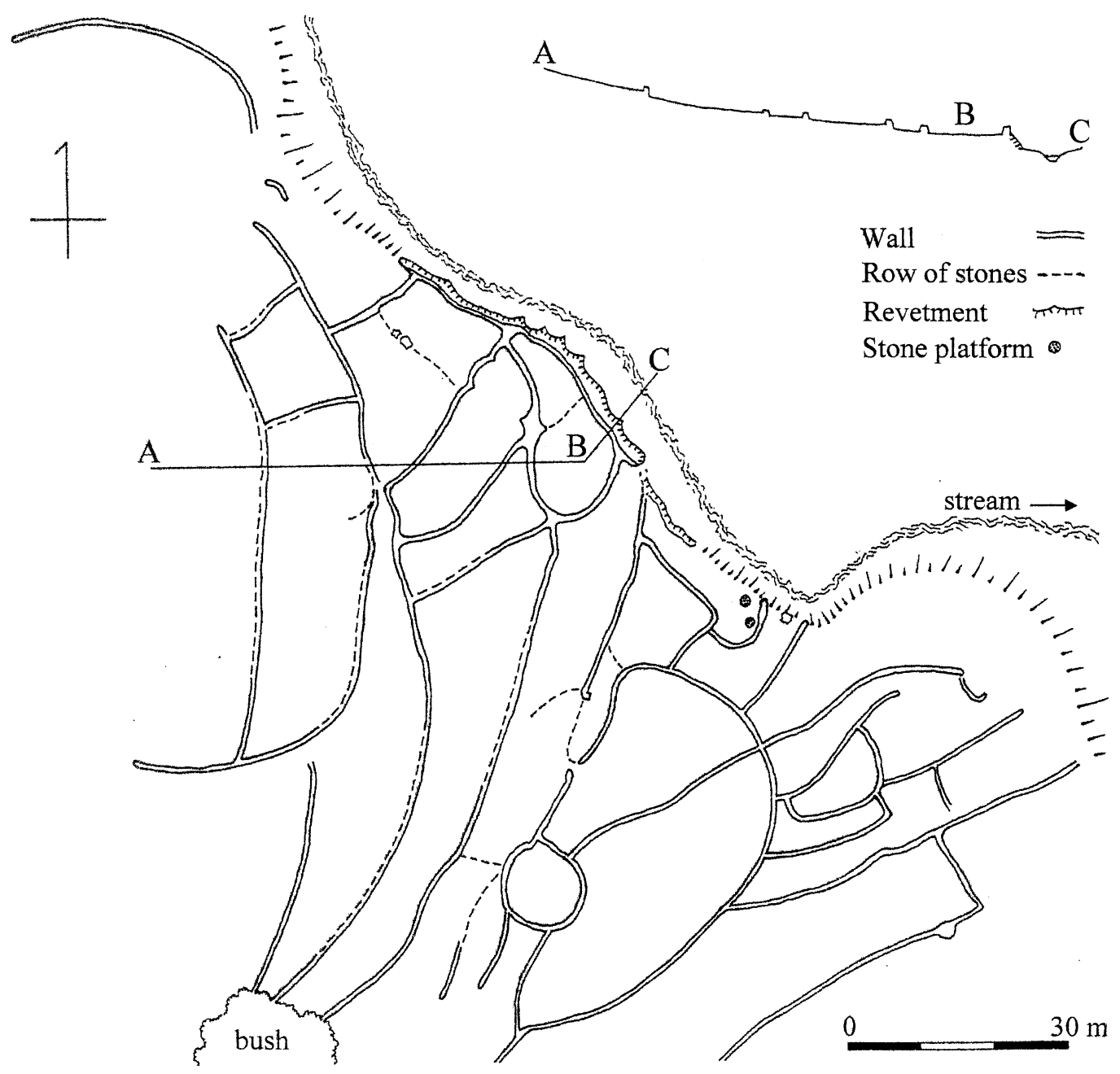

Figure 11. Detailed plan of a small part of the field system at Verlorenkloof, (mapped by Tim Maggs and Alex Schoeman 2009)

Examples of the features described above occur in the surveyed area. Apart from the terraces these include rock piles, stone lines and stone walls cutting across terraces to delineate plots. There is also an impressive band of stone revetment several metres high along the stream bank, evidently built to protect the terraced fields from flood damage. The revetment protrudes in a number of buttresses, which were presumably intended to give the structure more strength. In our Bokoni research to date we have seen such revetment only along this particular stream.

To examine the terrace structure a line was laid out to intersect three terraces, samples for dating and soil analysis being taken just uphill from the tallest of these. Excavated sections through the terraces revealed in detail how they had been constructed. In each case a line of upright slabs formed the uphill face (Fig. 12). The slabs showed careful selection being around 40 to $50 \mathrm{~cm}$ long and placed with this long axis vertically in what must have been a narrow trench to provide a barrier to runoff and soil erosion as described above under 'lines of upright slabs'. In two of the three terraces sectioned a second line of upright slabs had been added at a slightly higher level against the first line on the uphill side, evidently in response to 
further accumulation of soil moving downhill as cultivation continued over time. Immediately downhill from the line of slabs the soil had been dug or eroded away to a depth down to or below the base of the slabs. The resulting space was filled with small stones and rubble held in place by a well-built stone face, built to a slight batter, which formed the retaining wall of the terrace. It was noticeable that the stones of this face were aligned with their long axes into the wall, which would have afforded maximum resistance to downhill pressure from water and soil.

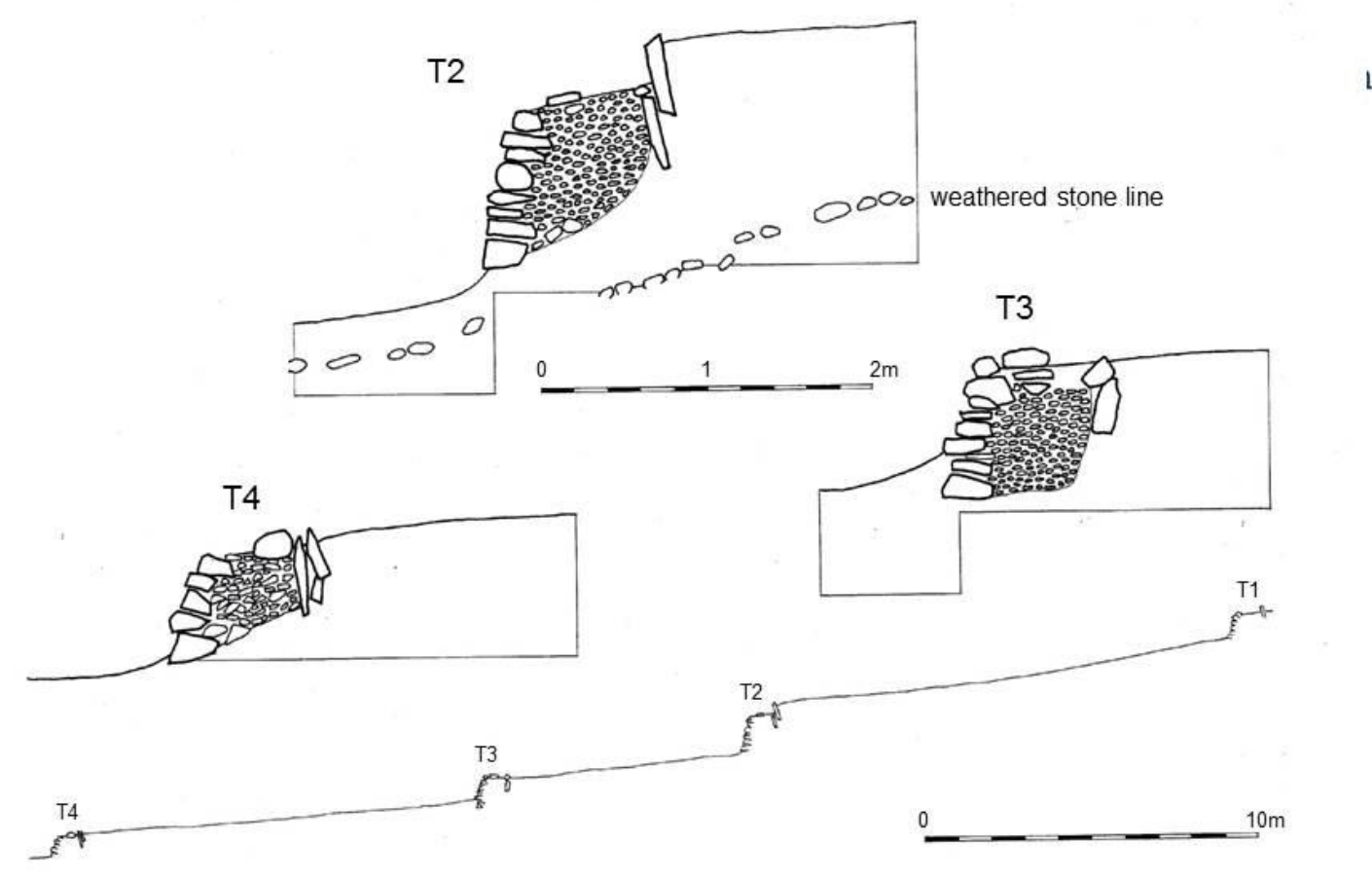

Figure 12 Section of terraces at Verlorenkloof. Drawing by Tim Maggs.

This pattern of terrace construction can therefore be seen as a combination of two of the techniques described above, namely the 'line of upright slabs' and the 'wall'. In effect it uses one face of a wall plus its rubble filling as the riser of the terrace, together with a line of slabs as the uphill margin. The pattern is clearly a Bokoni innovation; we have been unable to find similar terrace construction in reports from other parts of the world. Within the Bokoni region terraces of this pattern are best developed on sites like Verlorenkloof and Ohrigstad dam where thin slabs of sandstone/quartzite are readily available. We have, however, also recorded them on igneous substrates such as at Rietvlei where the available stones are more round or irregular in shape.

\section{Bokoni terracing: short-term or incremental change?}

The typology of techniques and features set out above provides us with a framework within which to discuss the growth and development of the terracing. One key to understanding the development of this intensive agriculture lies in the chronological and functional relations between the forms that are now visible on the surface. 
The walled cattle roads, the terracing and the other agricultural features in Bokoni form an important landesque capital, which was meant to last beyond the immediate growing season, and no doubt represents a major labour effort. The word capital in this context, does however not answer the questions of how such investments in the land came about. In some instances landesque capital investments may represent major, short-term labour efforts, such as in the case of long irrigation canals or massive terracing on steeply sloping and stony ground but, as much research has indicated, this does not have to be the case (Doolittle 1984, Börjeson 2004, Widgren 2004, Widgren \& Håkansson 2014)

The understanding of agrarian change, that emphasises major short-term investments, has by William E. Doolittle been termed a systematic view of agricultural change indicating that the structural transformation of the land would have to be completed before cultivation can start. Such a view is according to Doolittle "thought to involve inputs applied over short, discrete periods of time, and often to include planning, engineering expertise, and socially coordinated effort" (Doolittle 1984: 124). Doolittle also proposes an alternative, incremental view, whereby the changes in the land are more gradual: "individual fields and associated features, and ultimately the entire agroecosystem, are created by gradual upgrading through small units of input over long period of time while cultivation is taking place" (Doolittle 1984: 125).

The degree to which terracing in Bokoni represents massive short-term investments with large labour input over short periods or rather an incremental change over a comparatively longer period is one of the ongoing issues of our field investigations, and it has already been the subject of some discussion (Stump 2010, Maggs 2010). It has the potential to provide information on the social organisation, labour input and chronological span involved in the creation of the Bokoni landscape. In this paper we give some preliminary answers as a foundation for further research.

Some conclusions can already be drawn based on the material presented above. The existence of small stone cleared surfaces (Fig 3 type 1, Fig 4) shows that cultivation was indeed possible before formal terracing. The implements used for cultivation (hoes) and the absence of irrigation seem to have allowed for a wide range in size and shape of fields and terraced plots. These vary from the small plots of the stone-cleared surfaces which, most probably, did carry crops . Furthermore, drawing on the evidence of the Ohrigstad dam, a sequence of successive stone clearance and lynchet formation is evident on that particular site. In the $c .40$ $\mathrm{m}$ broad eroded zone around the dam lines of upright slabs and clearance cairns/rock piles have become exposed, while in the close vicinity upslope from the dam water levels a smooth system of lynchets is visible (Fig. 8). These lynchets probably developed on top of a primary clearing of rocks and some initial stone lines which have become buried as the lynchets developed. In this case an incremental system of lynchet formation as proposed in a sketch profile by Lindquist for Sweden (Lindquist 1968: 17) seems appropriate to explain the development.

How can we begin to look at short-term versus incremental construction of the formal terracing itself? For Burji-Konso in Ethiopia Amborn has shown different types of terracing, many of which seem to involve short-term construction (Amborn 1989). Similarly Soper has, for Nyanga, geographically the closest terrace system to Bokoni, proposed a sequence based on the idea of building a terrace, by clearing the land, building walls, turning back soil, building more on the wall and finally smoothing back the piled soil (Soper 2002: 45-46). This whole process must presumably be completed before cultivation can begin. In their overview of terrace typology and terrace formation in South America, mainly based on evidence from Peru, Treacy and Denevan describes the role of hand-fill vs. successive accretion of soil as 
parts of terrace-building/terrace forming processes. For bench-terracing, on steep slopes and aimed at horizontal terrace surfaces suitable for irrigation, a process similar to the one proposed by Soper is described. For more gently sloping land and rain-fed cultivation, with terraces that are allowed to have a slope on their planting surfaces of up to $20 \%$, the successive accretion of soil may play a larger role (Treacy and Denevan 1994: 96-104, see also Treacy 1987).

Returning to the Verlorenkloof terraces described above, we can begin to interpret the process of construction (Fig. 13). The initial step was evidently the establishment of a line of upright slabs roughly along a contour. With time soil accumulated against this line and in some cases a second line of slabs was added to hold the rising ground level. Meanwhile cultivation continued down-slope of the line on the next terrace surface. Our impression is that the cultivators were intent on tilling every possible suitable space. This produced a negative lynchet along the top of the field which would creep uphill and become deeper with time, eventually threatening to undermine the line of upright slabs. At this point it became necessary to support the steep slope of the negative lynchet by building the stone face of the terrace riser, backed by the rubble infill. The carefully built stone face might have been enough as a retaining wall but, the rubble core would have helped with the percolation of rainwater runoff and therefore reduced downhill pressure on the wall. ${ }^{9}$

\footnotetext{
${ }^{9}$ We thank Eric Johnson for help with this interpretation
} 

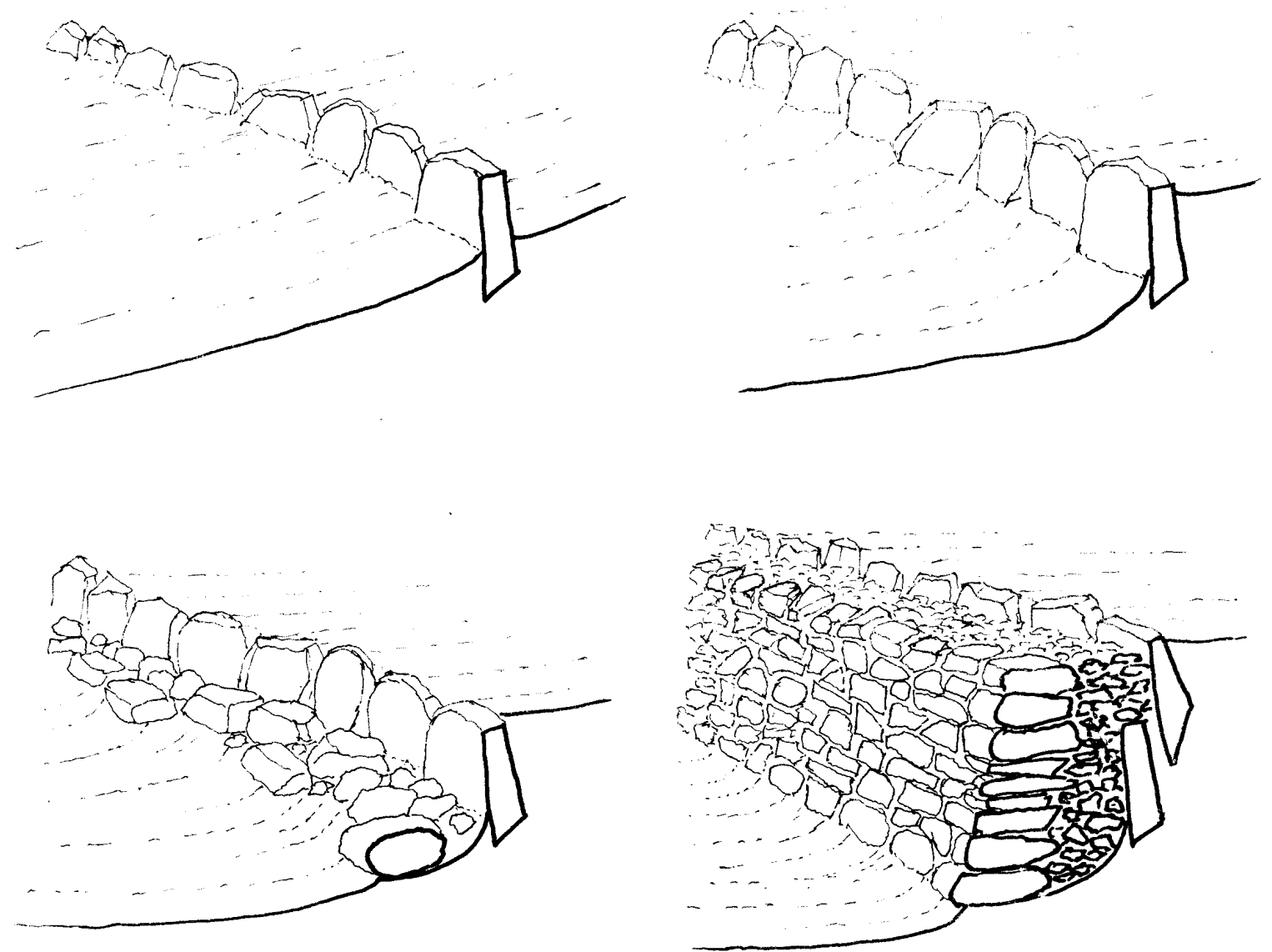

Figure 13. Suggested sequence of terracing at Verlorenkloof from a single line of upright slabs to a walled terrace (Drawings by Tim Maggs).

The implication of this construction sequence is that the initial line of upright slabs was established quite a while before the stone face of the terrace. The time interval must have been at least several seasons of cultivation for the development of a deep negative lynchet merely from hoe cultivation and the subsequent sheet wash. On stony slopes, as we have seen at Ohrigstad dam, loose stones disturbed by cultivation could be thrown onto the lynchet slope as it developed. This would produce a feature similar to the rock rubble terraces of Doolittle (2000) mentioned above, which may represent an intermediate stage between a mere stone line and a formal terrace. The evidence suggests an incremental development of these Bokoni terraces with an initial pulse of construction to lay down the line of upright slabs, followed several years later by a more intensive input of labour to build the stone face of the terrace riser. Maintenance and extensions to both face and stone line may also have required labour inputs over time.

The local environment of each patch of terracing would also have played a part in its development. An important factor here would be the immediate availability of rocks. Some slopes are so rocky that they probably could not have been successfully cultivated without at least some initial rough terracing. This, however, was not the case in the Verlorenkloof terraced area we researched. Here the underlying geology is mudstone/shale, which has weathered to a heavy red clay soil. The slopes would have had relatively little loose rock while this is abundant in and beside the stream (Fig. 11). The stream is a steep gradient, minor 
tributary of the Crocodile, one of the major rivers of the region, which flows in a 600 metre deep valley crowned by bold quartzite cliffs of Pretoria Group rock. This quartzite comprises most of the material of the terrace construction and we believe that much of it has been carried from beside the stream. In addition to rocks beside the stream we noted lobe-shaped deposits of unsorted rocks a little higher up the stream bed. These are typical of debris flow episodes caused by flash floods, examples of which are remembered by current residents of Verlorenkloof when the main farm road has been blocked by rock debris.

In our terrace excavations it was noticeable that the only strictly local stone, namely weathered rubble of mudstone/shale, was found in the rubble infill of the two upper terrace walls. The great majority of the upright slabs, stones of the riser faces as well as the rubble infill of the lower wall were of quartzite. Since much of this would have been carried up from the stream, any attempt to estimate the amount of labour required to build the terraces would have to take into account the amount of manual transport as well as the actual effort of terrace construction.

We are not yet sure how widespread this three-element stone terracing is in Bokoni. It occurs in predominantly sedimentary geological environments as at Verlorenkloof and Ohrigstad Dam, but we have still to examine the structure of terraces on sites like Rietvlei and Badfontein where the only available rock is from outcrops of intrusive lavas, which tend to produce irregular or rounded rocks.

\section{Soil development}

Just above the upper of the three excavated terraces the soil horizons were described and samples for analysis of siliceous microfossils, especially phytoliths were collected (Fig. 12, T2). Where the soil profile was described the soil is approximately $90 \mathrm{~cm}$ deep. It is composed of a clay-rich soil, reddish-brown in colour, which rests upon an in situ weathered saprolite. The parent material is most likely short-transported colluvium. Presence of weathered fragments of bedrock throughout the soil profile indicates that the material derives from eroded saprolitic material uphill. The manner in which the parent material has been deposited as a result of terracing is depicted in figure 15.

The description below is based entirely on the on-site examination, and the investigation enables tentative soil classification only. The terminology follows IUSS Working Group WRB (2014). 


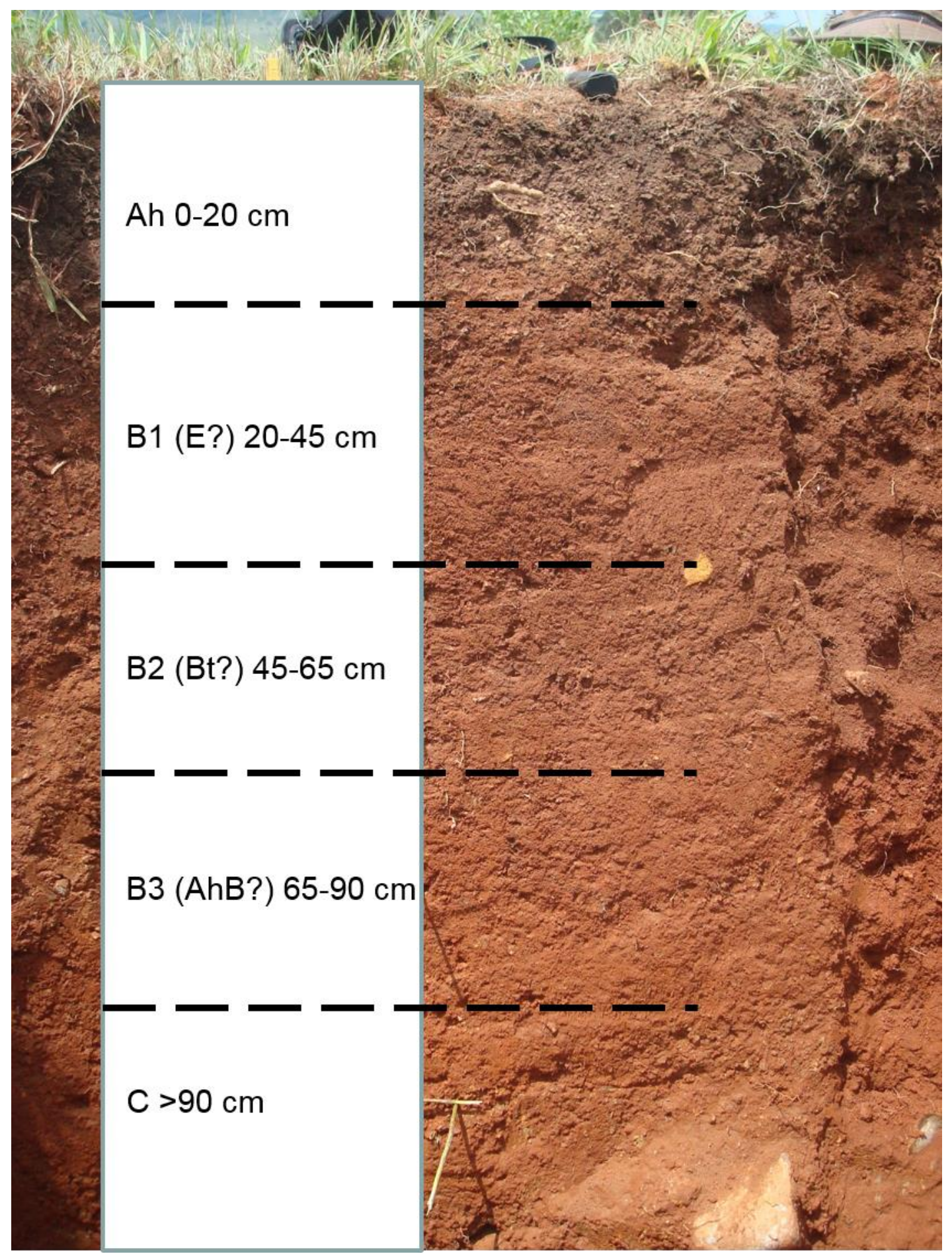

Figur 14. Soil profile of terrace T2 (cf Fig. 12) at Verlorenkloof.

The described profile has been divided in four horizons, excluding the C-horizon . Based on raised levels of organic carbon (OC) in the upper c. $90 \mathrm{~cm}$ of the profile (see below) we infer that some $60-70 \mathrm{~cm}$ of colluvium has been deposited on the original land surface, as a result of the terracing. The pre-terracing surface horizon would thus be approximately represented by the $65-90 \mathrm{~cm}$ horizon. Hoeing and other agricultural activities will have affected the added colluvium consecutively with the deposition. Hence, any naturally occurring deposition structure, e.g. sorting, cannot be expected. Consecutive tillage is probably also the cause of the evenly elevated content of OC between the present Ah-horizon and the C-horizon. 
A tentative soil classification to the reference soil group level is Luvisol (IUSS Working Group WRB 2014), i.e. a soil in which illuvial clay has accumulated in the B-horizon, producing an argic (argillic) horizon. Luvisols belong to the duplex soil group in the South African classification system (Fey 2010) and correspond to Alfisols in the Soil Taxonomy (Soil Survey Staff 2014).

Ah, 0-20 cm: Mollic or umbric surface horizon, with 1.1-3\% OC (increasing upwards). Grayish brown (5 YR 4/2). Silt loam, with common medium gravel-sized rock fragments. Granular to medium subangular blocky, soft to slightly hard structure. Gradual boundary to the next horizon.

B1(E?), 20-45 cm: Possibly an eluvial horizon, i.e. a horizon from which clay particles have migrated downwards. Bright reddish brown (5 YR 5/6). Silt loam, with common medium and coarse gravel-sized rock fragments and very few stones. Medium subangular blocky, soft to slightly hard structure. OC decreases downwards from a maximum level of c. $1.1 \%$ to $0.7 \%$ at the lower boundary. Gradual boundary to the next horizon.

B2 (Bt?), 45-65 cm: Possibly an illuvial (clay-enriched), argic horizon. Dull orange to orange (5 YR 7/4-6/6). Silt loam (possibly finer), with common medium and coarse gravel-sized rock fragments and very few stones. Medium subangular blocky, slightly hard structure. OC is stable at c. $0.7 \%$ throughout the horizon. Gradual boundary to the next horizon.

B3 (Ahb?), 65-90 cm: This is the lowermost horizon in which OC is raised (c. $0.7 \%$ in the upper part, down to c. $0.5 \%$ in the lower) in comparison with the saprolitic material beneath $(\mathrm{OC}<0.5 \%)$. There is therefore a possibility that this is the buried former land surface horizon that preceded terrace construction. The soil material is bright reddish brown (5 YR 5/8), but with slightly higher chroma than horizons above. Silt loam, with common to many medium and coarse gravel-sized rock fragments and very few stones. Medium subangular blocky, soft to slightly hard structure. Gradual boundary to the next horizon.

C, $\geq 90 \mathrm{~cm}$ : The upper $10 \mathrm{~cm}(\mathrm{c} .90-100 \mathrm{~cm})$ are composed of a loamy material with many medium to coarse gravel-sized rock fragments, and are interpreted as the upper part of the saprolite. Below c. $100 \mathrm{~cm}$ there are, in addition, abundant stone-sized, and few boulder-sized rock fragments. 

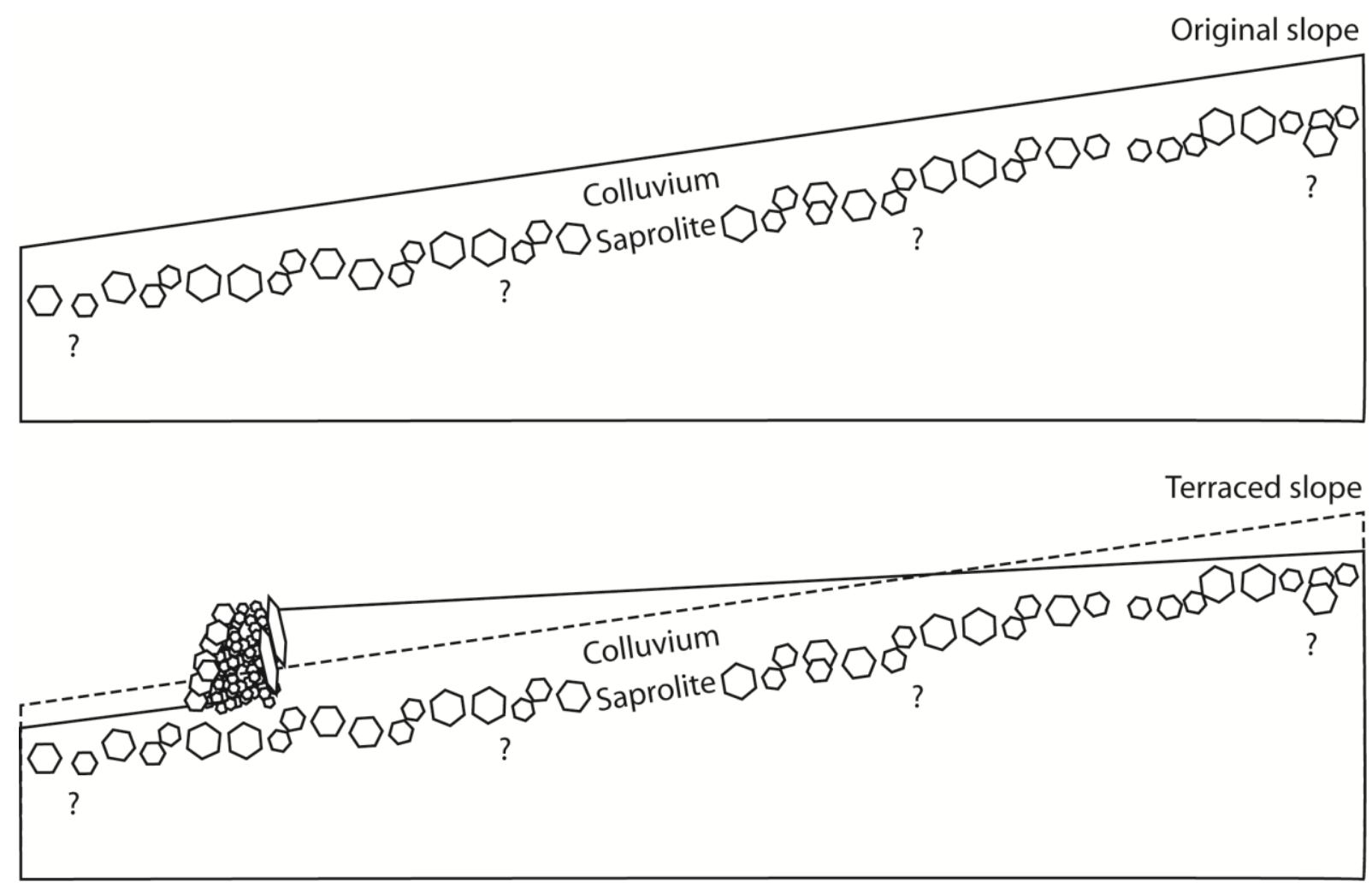

Figure 15 Sketch profiles showing the inferred development of terraces at Verlorenkloof through colluvial transport from upper to lower part of terraces.

Analyses of grass phytoliths are mainly applied for paleoclimate studies and in archaeological studies dealing with cultivation and cultivation history. The sub-division of phytoliths in this study is mainly based on Rossouw (2009), but complemented with the system by Cordova \& Scott (2010). The largest problem with phytolith analyses can be summarized by redundancy (formation of a certain morphotype in more than one taxa) and multiplicity (formation of several morphotypes in one taxa). An example of redundancy is that a small number of bilobate phytoliths are formed in Chloridoideae, Arundinoideae and Bambusoideae although this morphotype is characteristic for Panicoideae. Pooid morphotypes can also be found in Chloridoideae and Panicoideae, however, in small amounts (Breman 2010). The phytoliths have in this investigation been classified to the sub-family where they are most common.

Phytoliths from domesticated plants have been treated differently from those used for paleoclimate studies. They have been studied in detail in order to separate them from their wild ancestors, often with statistical methods based on size and morphological features (Iriarte 2003; Piperno 2006). Phytoliths from maize (Zea mays mays) are well studied and the possibilities to separate those are considered as relatively safe (Piperno 2006). Maize produces a certain type of rondels, and larger and wider cross shaped phytoliths, that differ from those produced by other grass species (Pearsall et al. 2004; Piperno 2006). Cross shaped phytoliths have been divided into 15 morphological groups whereof Group 1 is considered characteristic for maize (Piperno 2006). If $>50 \%$ of the cross shaped phytoliths belong to other groups, maize is probably not present. There are, however, grass species where size and morphology overlap those from maize. ${ }^{10}$ Some maize varieties could also produce small cross shaped phytoliths. With this as a background our interpretations should be considered as highly tentative.

\footnotetext{
${ }^{10}$ For examples of this in Africa, see Logan (2012: 93-96).
} 
The diagram is divided into four zones mainly based on the occurrences of cross shaped phytoliths identified as cf. Zea (Figure 16). The diagram is related to the established soil horizons. The zones are described below from bottom upwards.

Zone 1, 100-72.5 cm depth, is interpreted to represent the original $C(R)$ soil surface present at the site. It cannot be ruled out that less intense cultivation activities were performed initially prior to the construction of the terraces. This is based on the relatively high numbers of phytoliths in general and occurrences of Chrysophycean cysts.

Zone 2, 72.5-42.5 cm depth, contains two buried soil horizons, B3 and lower part of B2. Here, several finds of cross shaped phytoliths, indicating possible cultivation of maize, were made. The incremental accumulation of soil is supported by finds of aerophilic diatoms and even Fragilaria sp. at the top of the zone.

Zone 3, 42.5-27.5 cm depth, also contains two buried soil horizons, upper part of B2 and lower part of B1. This zone is barren of cross shaped phytoliths emanating from maize. Therefore it is tentatively suggested that maize was replaced by another crop.

Zone 4, 27.5-0 cm depth, is dominated by the upper Ah soil horizon. Here, it seems as cultivation of maize was re-established. Aerophilic diatoms are common and several observations of Fragilaria parasitica and F. construens v. venter at $15 \mathrm{~cm}$ depth indicate wet conditions (cf. Krammer \& Lange-Bertalot 1991). 


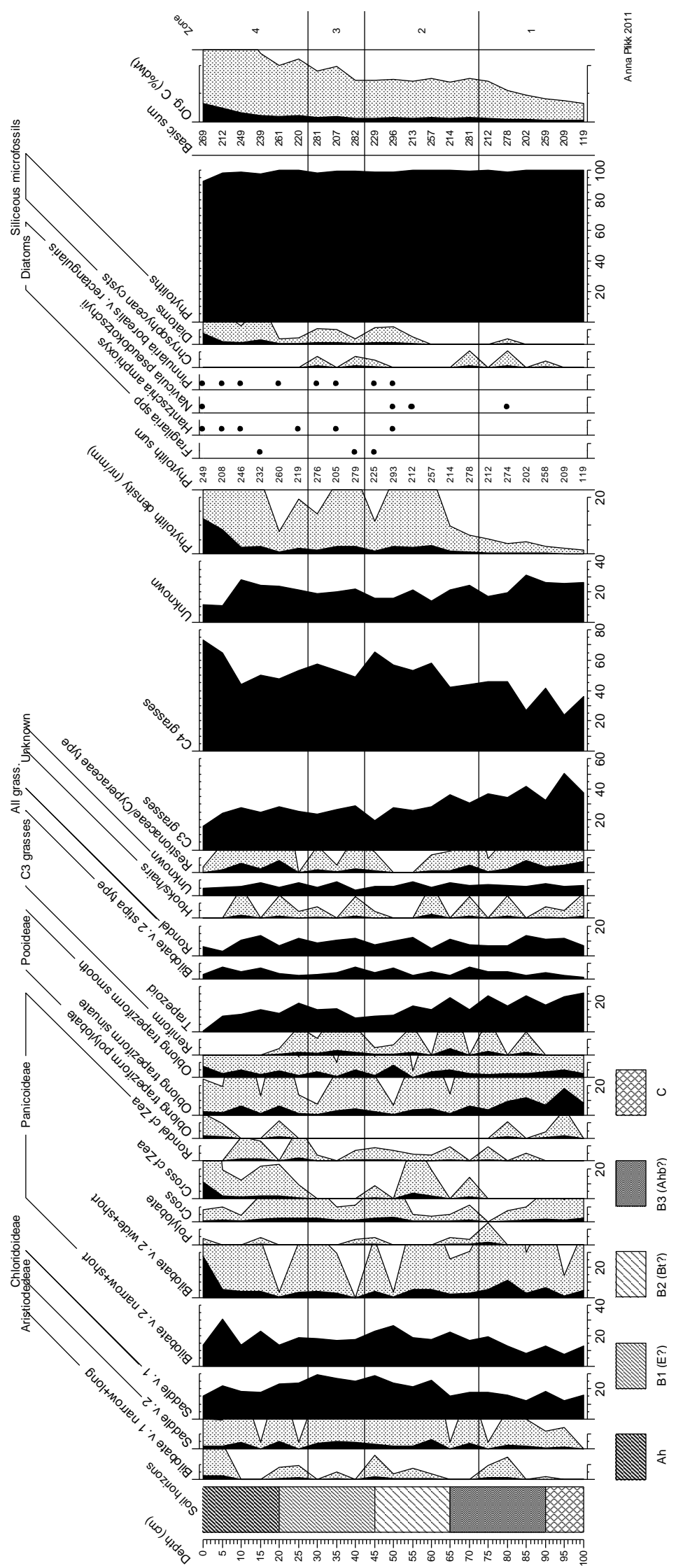

Figure 16 Siliceous microfossil diagram from Verlorenkloof

The analysis of the soil profile and its content of phytoliths speak in favour of the hypothesis that the terraces were incrementally developed. There are no indications that the material on 
the upslope side of the terrace riser was deposited instantaneously; rather it appears to be colluvial in nature, which implies a continuous and temporarily extended deposition as a result of slope processes. The increase in diatom occurrences slightly above the inferred original ground surface at $65 \mathrm{~cm}$ depth, zone boundary $1 / 2$, indicates slightly wetter conditions. Even though most species identified are aerophilic in nature (Pinnularia borealis v. rectangularis, Hantzschia amphioxys and Navicula pseudokotschyi), it can be concluded that after construction of the terraces, surface run-off was delayed causing moist condition in the lower part of the terrace. This increase in wetness was sufficient for the growth of these species and also Fragilaria spp in three of the samples. Also the increase in C4 phytoliths supports the interpretation of higher moisture upwards in the sequence. If the terraces had been constructed instantaneously, the amount of diatoms would have been low since the soil that built up the slope is free from these organisms. The relative higher organic carbon content, rising from c. 0.2 to $0.8 \%$, also speaks in favour of this interpretation.
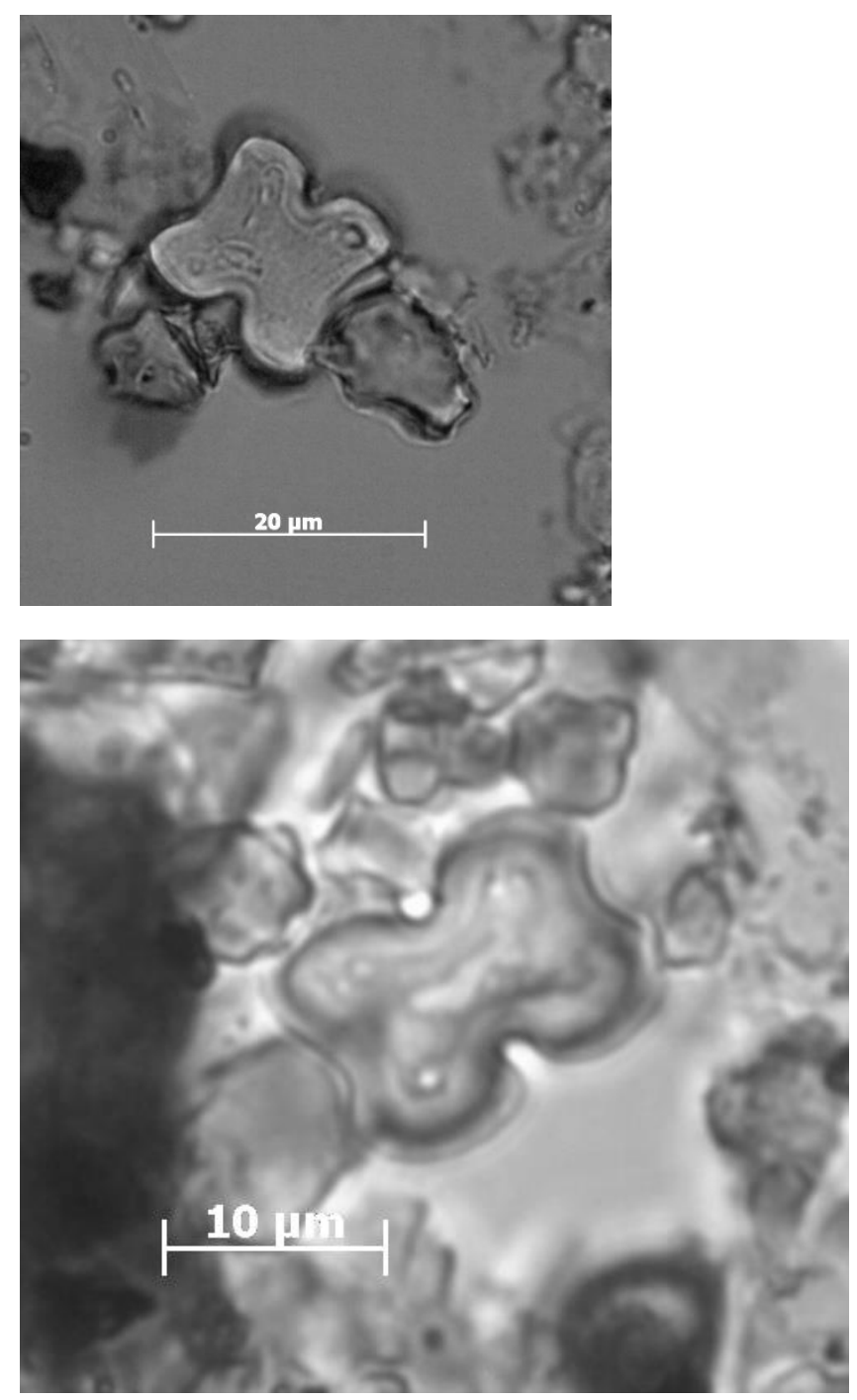

Fig. $17 a$ and $b$. Phytoliths from the section at Verlorenkloof tentatively determined as emanating from maize.

In our analyses the pictures shown in Piperno (2006: 200) have been used as a guidance to identify maize phytoliths. Examples of cross shaped phytoliths from our analyses are shown 
in Fig. 17. If these identifications are correct, maize was cultivated during two phases (Zone 2 and 4).

The question concerning the possible use of manure can be discussed on the basis of the stratigraphic occurrences of Chrysophycean cysts. These resting spores from golden algae are known to occur in high numbers when excessive nitrogen is available (Miller at al. 1979, Risberg et al. 2002). At Verlorenkloof, the percentages seldom reach 1\%; hence it is not possible to reach a conclusion.

\section{Conclusion}

The main result of this study is the typology of terracing and other agricultural features in the Bokoni areas within the broader framework of African, European and American research on ancient fields and terracing. This typology has made possible some preliminary conclusions relevant for the further analysis of the expansion and growth of the terracing and stonewalling in Bokoni. It has been shown that terracing on the site of Verlorenkloof must have been an incremental process, whereby cultivation, stone-clearing and terracing have been intermixed processes. As we have shown there are many pre-forms to the final building of properly faced terrace walls, and there is no reason to assume that terracing in Bokoni should be seen as a single major labour effort, which had to be concluded before cultivation could start. In Fig. 13 we have, based on the excavations in Verlorenkloof suggested a possible sequence of successive terrace formation. The sequence can be supported with field observations from Orighstad dam, but its validity needs to be tested on other sites as well. In the case of Bokoni we are thus arguing that terrace construction was part and parcel of yearly activities in clearing and tilling sloping land in a generally labour intensive agricultural system. The analysis of the soil profile in one of the terraces at Verlorenkloof also lends support to the hypothesis of an incremental process. This is supported both by the organic content and by the phytolith analysis. The phytolith analysis has furthermore given indications for the cultivation of maize, on the terraces, but this should be seen as a pilot study only, and presence of maize in Bokoni must be tested with a wider palette of palaeoecological methods.

To what extent the conclusion on incremental change in Bokoni may be valid also for other cases of terraced agriculture in Africa remains to be investigated. Where irrigation is involved and hence a horizontal surface is needed and/or where slopes are steep the building must of course have involved a discrete construction phase. This is the case for many of the terraces in Konso (Amborn 1989; Watson 2009, 33-37) and has also been shown for Pare, where the terrace aimed for irrigation, was cut into the slope (Stump 2010, 272). The sketch of bench terrace construction procedures as described by Treacy and Denevan (1994: 100) is here a reference. On less sloping land the possibility of an incremental process must be considered. Davies has shown such ongoing processes in Pokot (Davies 2014: 78-81), but for abandoned terracing, as Stump argues, the only way to solve the issue is through excavation (Stump 2010: 272). As has been shown by Soper, slopes vary in Nyanga, as do also the slopes of the terraced fields (Soper 2002; 35-54). It is possible that both discrete construction phases, as described by Soper, and more incremental processes may have been at work there.

\section{References}

Acabado, S. B. 2012. Taro before rice terraces: implications of radiocarbon determinations, ethnohistoric reconstructions, and ethnography in dating the Ifugao Terraces. In: M. 
Spriggs, D. Addison and P. J. Matthews eds. Irrigated Taro (Colocasia esculenta) in the Indo-Pacific. Osaka, National Museum of Ethnology, pp. 285-305.

Amborn, H. 1989. Agricultural intensification in the Burji-Konso cluster of south-western Ethiopia, Azania, 24, 71-83.

Aufrére, L. 1929. Les rideaux, Annales de Géographie, 216, 529-560.

Bevan, A., Conolly, J.,Colledge, S., Frederick, C., Palmer, C., Siddall, R., Stellatou, A. 2013. The Long-Term Ecology of Agricultural Terraces and Enclosed Fields from Antikythera, Greece. Human Ecology 41 (2), 255-272.

Boeyens. J. C.A. 2003. The Late Iron Age sequence in the Marico and Early Tswana. The South African Archaeological Bulletin 58 (178), 63-78.

Börjeson, L. 2004. A History under Siege: Intensive Agriculture in the Mbulu Highlands, Tanzania, 19th Century to the Present, Acta Universitatis Stockholmiensis, Stockholm.

Breman, E. 2010. Pattern and process in grass-dominated ecosystems: vegetation dynamics at the grassland-savanna ecotone in South Africa during the Holocene. Doctor of Philosophy Thesis, University of Oxford,

Carr, S. 2014. The challenge of Africa's nitrogen drought: Some indicators from the Malawian experience. International Food Policy Research Institute (IFPRI).

Collett, D.P. 1982. Excavations of stone-walled ruin types in the Badfontein valley, Eastern Transvaal, South Africa. The South African Archaeological Bulletin 37, 34-43.

Cordova, C.E. \& Scott, L. 2010. The potential of Poaceae, Cyperacea and Restionaceae phytoliths to reflect past environmental conditions in South Africa. In Runge, J ed : African palaeoenvironments and geomorphic landscape evolution, 107-133.

Davies, M. I. J. 2014. The temporality of landesque capital: Cultivation and and the routines of Pokot life. Landesque capital : the historical ecology of enduring landscape modifications.., Left Coast Press, Walnut Creek, pp. 176-196.

Delius, Peter. 1983. The land belongs to us: the Pedi polity, the Boers, and the British in the nineteenth-century Transvaal. Ravan Press, Johannesburg.

Delius, P. and Schoeman, M. H. 2008 Revisiting Bokoni,: populating the stone ruins of the Mpumalanga Escarpment, In: Swanepoel, N., Esterhuysen, A. and Bonner, P., eds., Five hundred years rediscovered: Southern African precdents and prospects, Wits University Press, Johannesburg, pp. 136-167

Delius, P. and Schoeman, M. 2010. Reading the rocks and reviewing red herrings, African Studies, 69 (2) , 235-254.

Delius, P., Maggs, T. \& Schoeman, A. 2014. Forgotten World: The stone-walled settlements of the Mpumalanga escarpment: : Wits University Press, Johannesburg.

Denecke, D. 1979. Zur Terminologie ur-und frügeschichtlicher Flurparzellierungen und Flurbegrenzungen sowie im Gelände ausgeprägter Flurrelikte: Grundzüge eines terminologischen Schemas. In: Beck, H., ed. Untersuchungen zur eisenzeitlichen und frühmittelalterlichen Flur in Mitteleuropa und ihrer Nutzung: Bericht über die Kolloquien der Kommission für die Altertumskunde Mittel- und Nordeuropas in den Jahren 1975 und 1976. T. 1, Vandenhoeck \& Ruprecht, Göttingen, pp. 420-440.

Doolittle, W. E. 1984. Agricultural change as an incremental process, Annals of the Association of American Geographers, 74, 124-137. 
Doolittle, W. E. 2000. Cultivated landscapes of native North America, Oxford University Press, Oxford.

Evers, T. M. 1973. Iron Age research in the eastern Transvaal, South Africa, 1971. Current Anthropology. 14, 487-488.

Evers, T..M. 1975. Recent Iron Age research in the Eastern Transvaal, South Africa. The South African Archaeological Bulletin. 30, 71-83.

Farré, I. \& Faci, J.M. 2006 Comparative response of maize (Zea mays L.) and sorghum (Sorghum bicolor L. Moench) to deficit irrigation in a Mediterranean environment. Agricultural Water Management, 83, 135-143.

Fey, M. 2010. Soils of South Africa, Cambridge University Press, Cambridge.

Frederic, C. D. and Krahtopoulou, A. 2000. Deconstructing agricultural terraces: Examining the influence of construction method on stratigraphy, dating and archaeological visibility. In: P. Halstead and C. Frederick eds. Landscape and land use in postglacial Greece, Sheffield Academic Press, Sheffield, pp. 79-94.

Fries, J. C. 1995 Vor- und frühgeschichtliche Agrartechnik auf den Britischen Inseln und dem Kontinent : eine vergleichende Studie, Internationale Archäologie,, Leidorf, Espelkamp.

Gren, L. 1997. Fossil åkermark : äldre tiders jordbruk - spåren i landskapet och de historiska sammanhangen, Fornlämningar i Sverige,, Riksantikvarieämbetet, Stockholm.

Grove, A. T. \& Rackham, O. 2001. The nature of Mediterranean Europe: an ecological history, Yale University Press, New Haven; London.

Grove, A. T. and Sutton, J.E.G. 1989. Agricultural terracing south of the Sahara. Azania 24, 114-122.

Hall, M. and Vogel, J. C. 1980. Some recent radiocarbon dates from Southern Africa. The Journal of African History, 21(4), 431-455.

Hall, M., and Maggs, T. 1979. Nqabeni, a later Iron Age site in Zululand. South African Archaeological Society Goodwin Series, 3, 159-176.

Hamilton, Caroline ed. 1996. The Mfecane aftermath: reconstructive debates in Southern African history. Witwatersrand Univ. Press, Johannesburg.

Hedges, D. 1978. Trade and politics in southern Mozambique and Zululand in the eighteenth and early nineteenth centuries. London University Ph.D. thesis.

van Hoepen, E.C.N. 1939. A pre-European Bantu Culture in the Lydenburg District. Argeologiese Navorsing van die Nasionale Museum, Bloemfontein, II (5), 47-74.

Huffman, T.N. 1996. Archaeological evidence for climatic change during the last 2000 years in southern Africa. Quaternary International, 33, 55-60.

Iriarte, J., 2003: Assessing the feasibility of identifying maize through the analysis of crossshaped size and three-dimensional morphology of phytoliths in the grasslands of southeastern South America. Journal of Archaeological Science 30, 1085-1094.

IUSS Working Group WRB. 2014. World Reference Base for Soil Resources 2014. International soil classification system for naming soils and creating legends for soil maps. World Soil Resources Reports No. 106. FAO, Rome. 
Kassougué, A., Momota, M., Sagara, J. and Schutgens, F. 1996. A measure for every site: traditional SWC techniques of the Dogon Plateau, Mali. In: Reij, C., Scoones, I. and Toulmin, C., eds., Sustaining the soil: indigenous soil and water conservation in Africa, Earthscan, London, pp.69-79.

Krammer, K. \& Lange-Bertalot, H., 1991: Bacillariophyceae. 3. Teil: Centrales, Fragilariaceae, Eunotiaceae. In: Ettl, H., Gerloff, J., Heynig, H., Mollenhauer, D. eds , Süsswasserflora von Mitteleuropa 2/3. Gustav Fischer Verlag, Stuttgart.

Lindquist, S.-O. 1968 Det förhistoriska kulturlandskapet $i$ östra Östergötland : Hallebyundersökningen I, Hallebyundersökningen,, Almqvist \& Wiksell, Stockholm.

Lindsay, A. J. 1961. The Beaver Creek agricultural community on the Sanjuan river, Utah, American Antiquity, 27 (2), 174-187.

Logan, A. 2012. A history of food without history: Food, trade, and environment in westcentral Ghana in the second millennium AD. Diss.Univ. of Michigan. http://deepblue.lib.umich.edu/handle/2027.42/96047 accessed June 30th 2015

Maggs, T. 1982. Mgoduyanuka: terminal Iron Age settlement in the Natal grasslands. Annals of the Natal Museum, 25, 83-113.

Maggs, T. 2008. The Mpumapanga escarpment settlements: some answers, many questions. In: Swanepoel, N., Esterhuysen, A. and Bonner, P. L., eds., Five hundred years rediscovered: Southern African precedents and prospects, Wits University Press, Johannesburg, pp. 169-181.

Maggs, T. 2010. The 2009 FYI Workshop and Excursion: Valuable Lessons from Eastern Africa, African Studies, 69 (2) , 213-217.

Maggs, T., Oswald, D., Hall, M. \& Ruther, H.1986. Spatial parameters of Late Iron Age settlements in the upper Thukela Valley. Annals of the Natal Museum, 27 (2) : 455479.

McCann J.C. 2005. Maize and grace Africa's encounter with a New World crop, 1500-2000. Harvard University Press, Cambridge, Mass.

Miller, U., Modig, S. \& Robertsson, A.-M., 1979. The Yttersel dwelling site: Method investigations. Early Norrland 12, 77-92.

Monnig, H. O. 1967. The Pedi, van Schaik, Pretoria.

Pearsall, D.M., Chandler-Ezell, K. \& Chandler-Ezell, A. 2004. Maize can still be identified using phytoliths: response to Rovner. Journal of Archaeological Science 31, 1029-1038.

Pijper, C. 1918. Some engraved stones of the Lydenburg District and Nort-East Transvaal: The occurrence of "Cup - and Ring" markings in South Africa. South African Journal of Science, 15, 413-427.

Piperno, D.R., 2006. Phytoliths. A comprehensive guide for archaeologists and paleoecologists. Altamira Press, New York.

Prinsloo, C.W. 1936. Klank- en vormleer van BaKoni. MA Dissertation. University of Pretoria, Pretoria.

Risberg, J., Bengtsson, L., Kihlstedt, B., Lidström Holmberg, C., Olausson, M., Olsson, E. \& Tingvall, C., 2002. Siliceous microfossils, especially phytoliths, as recorded in five prehistoric sites in eastern middle Sweden. Journal of Nordic Archaeological Science $13,11-26$. 
Rossouw, L. 2009. The application of fossil grass-ohytolith analysis in the reconstruction of late Cainozoic environments in the South African interior. PhD thesis, Department of Plant Sciences, University of the Free State, Bloemfontein South Africa.

Schoeman, M.H. 1998. Material culture 'Under the animal skin': Excavations at Esikhunjini, a Mfecane period Ndzundza Ndebele site. Southern African Field Archaeology, 7 (2) , $72-$ 81.

Soil Survey Staff, 2014. Keys to Soil Taxonomy, 12th ed. USDA-Natural Resources Conservation Service, Washington, DC.

Soper, R. 2002. Nyanga: ancient fields, settlements and agricultural history in Zimbabwe, The British Institute in Eastern Africa, London.

Spencer, J. E. and G. A. Hale 1961.The origin, nature and distribution of agricultural terracing. Pacific Viewpoint 2(1) 1-40.

Stump, D. 2006. Towards an applied archaeology of East African intensive agricultural systems, unpublished thesis University College London.

Stump, D. 2010. Intensification in context: archaeological approaches to precolonial field systems in Eastern and Southern Africa, African Studies, 69 (2), 255-278.

Sutton, J. E. G. 2000. Engaruka: an irrigation agricultural community in northern Tanzania before the Maasai, British institute in Eastern Africa, Nairobi.

Taylor, C. 1975. Fields in the English landscape, J.M. Dent, London.

Treacy, J. M. 1987. Building and rebuilding agricultural terraces in the Colca valley of Peru, Yearbook, Conference of Latin Americanist Geographers, 13, 51-57.

Treacy, J. M. \&Denevan, W. M. 1994. The creation of cultivable land through terracing. In Miller, N. F. and Gleason, K. L., eds., The Archaeology of garden and field, University of Pennsylvania Press, Philadelphia pp.91-110.

Widgren, M. 2004 Towards an historical geography of intensive farming in eastern Africa. In: Widgren, M. and Sutton, J. E. G., eds., Islands of intensive agriculture in Eastern Africa: past \& present, James Currey, Oxford, pp. 1-18.

Widgren, M. 2010a. Besieged palaeonegritics or innovative farmers: historical political ecology of intensive and terraced agriculture in West Africa and Sudan. African Studies 69 (2), 323-343.

Widgren, M. 2010b. Reading the prehistoric landscape. Ymer 130, 69-86.

Widgren, M. \& Håkansson, N.T. 2014. Landesque capital: what is the concept good for. In: Håkansson \& Widgren (eds) Landesque capital: the historical ecology of enduring landscape modifications, Left Coast Press, Walnut Creek, pp 9-30.

Wright, J. 2010. Putting Bokoni on the historian's map, African Studies, 69 (2), 229-233. 
Acknowledgements: The research for this article was funded by National Research Foundation (SA) and the Swedish Research Council under the Swedish-South Africa Research Links Programme. At Verlorenkloof we benefited greatly from the cooperation and hospitality of Eric Johnson and his staff. They had previously cleared dense vegetation from an area of well-built terracing. Thanks are also due to Chris Taylor for permission to reproduce Fig. 7 and to Robert Soper and an anonymous referee for valuable suggestions. 